\title{
The Microstructure of the Bond Market in the 20th Century*
}

\author{
Bruno Biais ${ }^{\dagger}$ \\ and \\ Richard C. Green $\ddagger$
}

August 29, 2007

* Part of this paper was written as Biais was visiting the NYSE. We are grateful for the support and information provided by the Research Department and the Archives of the New York Stock Exchange and discussions with Paul Bennet, Mark Gurliacci, Pam Moulton, Steve Poser, Bill Tschirhart, Li Wei and Steve Wheeler. We are also indebted, for helpful discussions and information, to Amy Edwards, Liam Brunt, Paul David, Jim Jacoby, Ken Garbade, Tal Heppenstall, Phil Hoffman, Edie Hotchkiss, Allan Meltzer, Mike Piwowar, Jean-Laurent Rosenthal, Norman Schürhoff, Chester Spatt, Ilya Strebulaev, Eugene White, Luigi Zingales and seminar participants at the SEC seminar, the University of Lausanne seminar, the Toulouse conference in honour of Jean Jacques Laffont and the Paris School of Economics workshop on economic history. Dan Li, Charles Wright, Joanna Zeng, and especially Fei Liu provided excellent research assistance. Financial support was provided by the Hillman Foundation.

${ }^{\dagger}$ Toulouse University (Gremaq/CNRS, CRG/IAE, IDEI)

†Tepper School of Business, Carnegie Mellon University 


\title{
The Microstructure of the Bond Market in the 20th Century
}

\begin{abstract}
Bonds are traded in over-the-counter markets, where opacity and fragmentation imply large transaction costs for retail investors. Is there something special about bonds, in contrast to stocks, precluding transparent limit-order markets? Historical experience suggests this is not the case. Before WWII, there was an active market in corporate and municipal bonds on the NYSE. Activity dropped dramatically, in the late 1920s for municipals and in the mid 1940s for corporate, as trading migrated to the over-the-counter market. The erosion of liquidity on the exchange occurred simultaneously with increases in the relative importance of institutional investors, who fare better in OTC market. Based on current and historical high frequency data, we find that average trading costs in municipal bonds on the NYSE were half as large in 1926-1927 as they are today over the counter. Trading costs in corporate bonds for small investors in the 1940s were as low or lower in the 1940s than they are now. The difference in transactions costs are likely to reflect the differences in market structures, since the underlying technological changes have likely reduced costs of matching buyers and sellers.
\end{abstract}




\section{Introduction}

Bonds are mostly traded through decentralized, dealer intermediated, over-the-counter (OTC) markets. Stocks, on the other hand, are for the most part traded on organized exchanges. On OTC markets there is little pre-trade transparency, as dealers do not post publicly accessible firm quotes. Furthermore, only dealers can provide quotes, and thus investors do not compete directly to supply liquidity.

How efficient is this markets structure? This is a central question for investors, policy makers and researchers alike. Are the differences in the structure of the markets on which different types of securities trade an efficient response to the needs of the different types of investors holding those securities? Is it inherently problematic to trade bonds on a transparent limit-order book? Or, are differences in market structures the result of institutional inertia or the influence of entrenched interest groups? Could mandated changes in disclosure of price and volume information, or in the mechanisms through which trade is organized, lower costs for investors? Or, would such regulatory interference simply suppress a natural diversity in institutional arrangements benefiting all investors?

Answers to these questions are difficult to obtain through cross-sectional comparisons of existing markets because volume, prices, and trading mechanisms are all jointly endogenous variables. Perhaps corporate and municipal bonds have low liquidity and high trading costs because they are traded in opaque and decentralized dealer markets. Alternatively, perhaps they trade over the counter because the infrequent need for trade, and sophistication of the traders involved, renders the continuous maintenance of a widely disseminated, centralized limit-order book wasteful and costly.

We believe the historical experience can shed light on these questions, because it has not always been the case that equities and bonds were traded in such different venues. Until 1946, there was an active market in corporate bonds on the NYSE. In the 1930s, on the Exchange, the trading volume in bonds was between one fifth and one third of the trading volume in stocks. In earlier periods, there was also an active market for municipal bonds and government bonds. Indeed, the first organized exchange in New York, from which the modern NYSE traces its descent, was established by a group of brokers "under the buttonwood tree" to trade U.S. government bonds. Municipal 
bond trading largely migrated from the exchange in the late 1920s, and volume in corporate bonds dropped dramatically in the late 1940s. ${ }^{1}$ Since this collapse, bond trading on the Exchange has been limited.

This historical evidence shows that an active bond market with a centralized and transparent limit-order book was feasible. This, in turn, raises other questions. Why did liquidity dry up on the NYSE? Why has it been so difficult for the exchange to regain volume despite its periodic attempts to do so? What were the consequences for transactions costs of the migration of bond trading to the OTC market?

To answer these questions we first provide institutional information on the microstructure of the bond market in the twentieth century. We then consider possible explanations for the drop in the liquidity of the bond market on the Exchange. First, we ask whether decreases in liquidity could have been associated with changes in the role of bond financing generally. Based on data assembled from different sources (Federal Reserve, NBER and Guthman (1950)) we show that bond financing actually grew during the periods when trading volume collapsed on the Exchange.

Second, we ask whether the drop in liquidity could have resulted from SEC regulations increasing the cost of listing on the Exchange. We show that the decline in liquidity was not correlated with a decline in listings. Furthermore, while Exchange trading disappeared in securities that were exempt from the 1933 and 1934 acts (such as municipal bonds), it remained active in securities which were subject to this regulation (most notably stocks).

A third possible explanation focuses on the interaction between classes of traders with different preferences. It is widely recognized that there are positive externalities in liquidity (see for example Admati and Pfleiderer (1988) and Pagano (1989)). Traders prefer to route their orders where they expect that they will find liquidity - where they expect the other investors to have sent their orders. These complementarities give rise to multiple equilibria. While each of these equilibria can be locally stable, it can be upset by an exogenous shock, or a change in the characteristics of the players. Different equilibria will vary in terms of their attractiveness for different categories of market participants. Intermediaries benefit when liquidity concentrates in venues where they earn

\footnotetext{
${ }^{1}$ The historical evolution of trading volume in municipal and corporate bonds is documented in the present paper. The Treasury and Federal Study of the Government Securities Market, published in July 1959, mentions (Part I, page 95) that trading volume in Treasury securities migrated from the NYSE to the OTC market during the first half of the 1920s.
} 
rents, such as opaque and fragmented markets. For reasons we will show were quite evident to observers at the time, large institutional investors fare better than retail investors in a dealership market. This was especially true on the NYSE until 1975, because commissions were regulated by the Constitution of the Exchange, while intermediary compensation was fully negotiable on the OTC market. We find that liquidity migrated from the exchange to the OTC market at times when institutional investors and dealers became more important relative to retail investors. As institutions and dealers became more prevalent in bond trading, they tipped the balance in favor of the over-the-counter markets.

To evaluate the impact on trading costs, we collected high frequency data on transactions and quotes for 6 corporate bonds from 1943 through 1947 and 6 municipal bonds between 1926 and 1930. We chose these dates because they bracket the periods during which liquidity vanished from the Exchange for municipal bonds and then for corporate bonds. We find that price impact (the absolute value of the difference between the transaction prices and the mid-quote) was flat as a function of trade size in the NYSE bond limit-order market. In modern equity limit-order markets price impact rises with trade size, while trading costs fall dramatically with trade size in modern OTC markets. Average transactions costs were substantially lower in the late 1920s for municipal bonds than they are today. In the 1940s, despite fixed commissions, costs for retail investors trading corporate bonds were as low or lower than they are today in OTC markets. We believe this is quite striking. The natural or potential liquidity of these bonds is unlikely to have been higher historically than it is today, and the availability of counterparties is likely to have improved, since a much larger portion of the population invests and the population is much larger. More obviously, the cost of finding counterparties and processing trades is likely to have decreased, given the improvements in communication and data processing technology. These technological changes have dramatically reduced the costs of trading in other sectors of the economy.

Municipal bonds are a particularly interesting security to study in this context. The interest on the bonds is tax-exempt, and retail investors are therefore a significant presence in the market, as they are with equities. ${ }^{2}$ Migration of liquidity from the Exchange to the OTC market is most

\footnotetext{
${ }^{2}$ The other types of securities we observe trading through broker-dealer markets are now largely held by institutions. Corporate and treasury bonds in the U.S. are relatively unattractive to individual investors, as interest is taxed as ordinary income, at high rates in comparison to the returns on stocks. (See Dammon, Spatt, and Zhang (2004).) They are accordingly more naturally held through intermediaries in tax-deferred or tax-free entities.
} 
costly for retail investors. ${ }^{3}$ Our high-frequency data shows there was a striking drop in municipal bond trading on the NYSE in the late 1920s. At that time trading volume in equities was soaring. The Exchange was desperately short of capacity. (See Davis, Neal and White (2005).) The NYSE decided to reallocate capacity from relatively inactive bonds towards stocks, which were more profitable for the floor traders. Simultaneously, retail investors, attracted to equities by the large recent returns, lost their appetite for municipal bonds, leaving investment in this market to institutions. At this point, trading activity in municipal bonds rapidly migrated to the OTC market. This experience illustrates how shocks can lead to shifts in the focal point for trading. The difficulty of reversing such shifts once they have occurred (even if the conditions triggering the shift change) is illustrated by the inability of the Exchange to regain volume in municipal bonds, even when equity trading dropped relative to bonds during the years of the Great Depression.

A series of recent papers have shown empirically that the microstructure of the bond market can generate large transactions costs, and that the costs of trade are much higher for smaller trades. As Mende, Menkhoff, and Osler (2004) point out, this runs contrary to models of microstructure based on asymmetric information. In their study of the market for municipal bonds, Harris and Piwowar (2006) write: "Our results show that municipal bond trades are significantly more expensive than equivalent sized equity trades." That bonds command larger transactions costs than stocks, at least for small and medium sized trades, is surprising. Risk is one of the main components of the cost of supplying liquidity. Bonds are less risky than stocks. They should have lower spreads. Harris and Piwowar (2006) suggest that such large transactions costs reflect the lack of transparency of the bond market. Another empirical study of the municipal bond market, Green, Hollifield, and Schürhoff (2007a), estimates a structural model of bargaining between dealers and customers, and concludes that dealers exercise substantial market power. Green, Hollifield, and Schürhoff (2007b) show that when municipal bonds are issued, there is a large amount of price dispersion and that some retail investors receive pay very high transaction costs, despite the high level of volume in the bonds. In their studies of the corporate bond market, Edwards, Harris and Piwowar (2007), Goldstein, Hotchkiss and Sirri (2007) and Bessembinder, Maxwell, and Venkataraman (2007) show

\footnotetext{
${ }^{3}$ Bernhardt et al (2005) show theoretically that, in dealer markets, imperfect competition will lead to greater transactions costs for retail trades, and offer empirical evidence that this was the case for equities on the London Stock Exchange when it was a dealer market.
} 
that the lack of transparency in the corporate bond market led to large transactions costs, while the recent improvement in post-trade transparency associated with the implementation of the TRACE system lowered these costs for the bonds included in the TRACE system.

While these papers all suggest that the relatively large transactions costs facing bondholders are due to OTC structure of the bond market, they cannot speak to what the costs would be if the bonds were traded in limit-order book. The historical experience offers an opportunity to observe such trading.

In the next section we review the organization of the bond market in the 20 th century. In Section 3 we describe our data sources. In Section 4 we review some candidate explanations for the migration of bond market liquidity off the exchanges. Sections 5 and 6 consider the trading and trading costs for corporate bonds in the 1940s and municipal bonds in the 1920s, respectively, using transactions data from the NYSE. Section 6 offers additional remarks on convertible bonds and stocks. Section 8 concludes.

\section{The Organization of Bond Trading in the 20th Century}

Corporate and municipal bonds have historically been available both on organized exchanges and on over-the-counter markets, with the relative importance of these venues changing over time. A few mechanical aspects of the trading process are similar across the different venues. Prices on long-term bonds have traditionally been expressed as percentage of par, with trading in eighths, except for Treasuries which trade in finer increments. ${ }^{4}$ In other respects the trading process on the exchange differs dramatically from its counterpart over-the-counter. In this section we describe the mechanics of bond trading on the NYSE and in the OTC market in the twentieth century. We also summarize the discussion by market participants from the 20 s to the 50 s of the relative roles and merits of the two market venues. Our sources for this information are the books and publications to which we had access at the Archives of the NYSE. ${ }^{5}$ We also benefited from useful discussions with brokers who operated in the bond market on the NYSE in the 1950s.

\footnotetext{
${ }^{4}$ Today, corporate bond prices are decimalized.

${ }^{5}$ We are very grateful for the kind hospitality and help of the Archives department of the NYSE, especially Steve Wheeler.
} 


\subsection{Bond Trading on the NYSE}

Since 1872 , specialists have been responsible for providing liquidity and maintaining continuous prices for equities. In contrast, bond trading on the NYSE has always been purely "order-driven." The Exchange simply collects, posts and matches the orders of customers and the brokers acting for them. The physical separation of bond from stock dealing took place in 1902, when the so called "bond crowd" was formed. Until the 1920s, bond trading took place in the same room as stock trading. Trading in the "bond corner" was organized around three booths in the North East corner of the Exchange (see Meeker, 1922). As trading in bonds increased, it was allocated more and more space. In May, 1928, the "bond room," located at 20 Broad Street, and connected directly with the NYSE floor, was opened for trading (NYSE Fact Book, 1938). This was part of a general program to increase capacity on the exchange in response to the increases in volume in the 1920s (see Davis, Neal, and White, 2005).

Investors trading on the Exchange must pay commissions to the brokers facilitating the trade. Until 1975, commissions were regulated by the Governing Committee of the exchange. Our intraday data on bond transactions comes from two periods, the 1920s for municipals and the 1940s for corporates. The constitution of the NYSE, with amendments to November 25, 1927, states the commission rates in its Article XIX. For bonds, the relevant rules are as follows:

Sec. 2. Commissions shall be as follows:

(a) On business for parties not members of the exchange...

On Bonds: Not less that $\$ 2.00$ per $\$ 1,000$ value.

(b) On business for members of the Exchange when a principal is not given up...

On bonds: Not less than 80 cents per $\$ 1,000$ value.

(c) On business for members of the Exchange when a principal is given up...

On bonds: Not less than 40 cents per $\$ 1,000$ value...

(d) On obligations of the United States, Porto Rico, Philippine Islands and States, Territories and Municipalities therein... Such rates as members or non-members as may be mutually agreed upon.

Thus, commissions were already deregulated for Treasuries and municipal bonds in the 1920s. For the other bonds, commissions were regulated but were lower than for stocks. For example, on stocks priced between $\$ 10$ and $\$ 25$, for parties not members of the exchange, the minimum commission could not be less than 12.5 cents per share traded. Hence, for the sale of 50 shares, at a unit price of $\$ 20$, the commission would have to be above $\$ 6.25$, substantially above the $\$ 2$ 
threshold prevailing for bonds.

By the 1940s, minimum commissions had risen. (Recall that in New Deal securities regulations raised trading costs and imposed constraints in a number of areas.) The commission schedule also made explicit concessions for trade size. Table 1 shows the commission schedule prevailing in the late 1940s, which we obtained from the NYSE archives. The minimum denomination of the bonds was $\$ 1,000$, and the body of the table gives the commission per $\$ 1,000$ of par value traded. For example, the second line of the top panel indicates that a non-member purchasing three bonds with $\$ 1,000$ par value at a price of $\$ 99$ per $\$ 100$ of par value would pay a commission of $\$ 2.00$ per bond, or $\$ 6.00$ total.

Meeker (1922) and Shultz (1946), who were economists at the NYSE, offer very detailed descriptions of the bond trading process on the exchange. Meeker (1922) explains that in the "bond corner" trading in foreign bonds and Liberty Bonds was conducted in the two smaller booths, while the other bonds were traded in the third, and largest, bond booth. For the more recent period, Shultz (1946) explains that the "bond room" was divided in four separate divisions: the "active crowd", the "inactive" or "book" or "cabinet" crowd, the foreign crowd, and the Government securities crowd. Frequently-traded domestic bond issues were assigned to the active crowd. Active bonds were traded on the open outcry floor market. Meeker (1922, page 163) reports that:

In the case of market orders in the active bonds, whose prices are reported on the right side of the quotation board, the broker after noting the latest price on the board, goes directly to the bond crowd and effects a sale at the most favorable bid or asked price he can obtain.

Shultz (1946) offers a detailed example of order placement and trading in the "active crowd":

Broker A's telephone clerk on the floor receives an order over the direct telephone wire from his office to buy 5 Atchison General 4s of 1995 at 106. He makes out a "buy" order blank and hands it to his broker, who proceeds to bid for the bonds in the crowd. There are no immediate sellers so Broker A leaves the center of the crowd for the time being. The quotation clerk makes a notation to the effect that Broker A is bidding 106 for the bonds. Broker B's telephone clerk then receives an order from his office to sell 3 Atchison General 4s at 106 $\frac{1}{4}$. A "sell" order slip ... is made out and handed to broker B, who offers the bonds in the crowd. The quotation clerk records on his slate that Broker B is offering Atchison General 4s at $106 \frac{1}{4}$. A short time later Broker C's telephone clerk gets a call from his office for a "quote" on Atchison General 4s. The quotation clerk informs him that the market is $106-\frac{1}{4}, 106 \mathrm{bid}$, offered at $106 \frac{1}{4}$. The telephone clerk relays this information back to his office and shortly thereafter receives an order to sell 10 bonds at 106. Broker C takes the "sell" order slip, enters the crowd and learns from the 
quotation clerk that Broker A is bidding 106 for the bonds... Broker A "takes" 5 at 106 and broker $\mathrm{C}$ reduces his offer to 5 Atchison General 4s at 106. The quotation clerk changes his record to show the new offer and erases Broker A's bid.

The majority of the listed domestic bonds, however, were traded in the inactive, or cabinet, crowd. In the inactive crowd, all orders were written on standard slips and filed in the bond "cabinets" or "ledgers." This was, in effect, a limit-order book, collecting firm buy and sell orders and enforcing time and price priority. Apart from the manual technology, the workings of the "bond cabinet" are very similar to those of electronic order books in the 21st century, such as Euronext, Xetra, Sets, or Inet. Meeker (1922, page 161) writes:

Since most bonds are relatively inactive, the bid and asked quotations for them are kept on the bond ledgers... Under the name of a given bond issue, the clerk inscribes the various bid and ask quotations for it, as well as the amounts of bonds to be purchased or sold and the initials of the various brokers and dealers from whom he received the information. When these bid and ask quotations are for any reason withdrawn by the bond men, they are erased from the ledger. A bond man can thus learn the market for any inactive bond which he may desire to purchase or to sell, by asking the ledger clerk.

Shultz (1946) provides a detailed illustration the workings of the cabinet:

For example, Broker A's clerk receives an order to sell 5 Peoples' Gas, Light and Coke $5 \mathrm{~s}$ of 47 at 116. He makes out a "sell" order slip and takes it to the cabinet to which the particular bond issue is assigned. The order is handed to a "bond clerk," a Stock Exchange employee who files the order... Broker B's clerk then hands the bond clerk an order to sell 30 Peoples' Gas, Light and Coke $5 \mathrm{~s}$ of 47 at 116. This order is placed behind Broker A's order, notwithstanding the size of Broker B's offer. Broker C's clerk later enters a "buy" order for the same issue calling for 15 bonds at $115 \frac{3}{4} \ldots$ The quotation would now be " $115 \frac{3}{4}-116,15$ and $35 " .$. Broker D receives an order to buy 25 Peoples' Gas 5s at 116. Inasmuch as Broker A has priority as to time, his order for 5 bonds is completely filled and broker B then sells 20 bonds to broker D.

Once the trades had been completed, they were widely disseminated. Meeker (1922, page 161) explains that:

Reporters obtain the prices of sales as they occur in the bond crowd, make out slips and pass them to the board boys, who at once post the prices on the board - if the bond is one which is recorded there. Simultaneously they inform the telegraph operator, and very shortly afterward the quotations appear on the bond tickers throughout the country.

Thus, the bond market on the NYSE enjoyed a very high level of pre- and post-trade transparency. All brokers could observe the book of available orders and the recent trades, and inform 
their customers about them. In 1976, the NYSE introduced the Automated Bond System, an electronic order book with full price and time priority. This system is still in use today, but activity confined to a relatively small number of retail trades. More than 1000 bond issues are still listed on the Exchange, including Treasury bonds, Corporate bonds (e.g., General Motors), Utility bonds (Baby Bells), State bonds (e.g., State of California bonds), and Municipal bonds (e.g., NYC bonds). In all these cases, however, the overwhelming majority of trades are conducted over the counter.

\title{
2.2 The Over-The-Counter Market
}

While many bonds are (and have traditionally been) exchange listed, many more are (and have traditionally been) unlisted. Unlisted bonds trade over the counter, in a market based on bilateral, informal contacts between dealers. Listed bonds have traditionally been traded OTC as well as on the Exchange. Bond dealers typically maintain inventories in the securities for which they "make markets." A good description of the over-the-counter market at that time is offered in an investment analysis text published by an NYU professor in 1946:

\begin{abstract}
The market in over-the-counter securities is made by dealers within and between their offices at prices established by individual negotiation, that is, through bid and ask prices... A dealer creates and maintains a market for any issue of bonds or of stock by announcing openly to the other dealer and broker houses that he stands ready both to buy and sell that security at the bid price and the offering price that he quotes to those who inquire... The securities houses that act as dealers or brokers in the over-the-counter market include investment banking houses, over-thecounter houses, municipal bond dealers, government bond dealers, stock exchange firms which operate over-the-counter trading departments, and dealer banks... A house that makes a market in an issue usually "maintains a position" in the security by trading (buying and selling) against its position in the issue. It buys and sells for its own account and risk as principal... Unlike exchanges, where sales in a particular security are concentrated at one post on the exchange floor and the actual prices at which the security is sold are reported, the over-the-counter market is unable to report all transactions in a security. (Prime, 1946, pages 60 to 63.)
\end{abstract}

In contrast with the exchange, there are no explicit commissions in the over-the-counter market. In the words of Gellermann (1957, page 104):

...the price charged by the over-the-counter dealer will be a net price - no mention will be made of a commission, but you can be sure that the equivalent of a commission, or more, will be included in the price. 
In addition to the regulation of commissions, a key difference between the NYSE and the OTC market lies in their relative transparency. On the Exchange orders and transactions prices are recorded and made available to the public. On the OTC market, up to the very recent past, the transactions prices were not recorded in any central location, nor were the dealers under any obligation to disclose them. Transparency, however, is an endogenous outcome. It would be premature to conclude that the institutional setting is the cause of the lack of transparency. Both the trading venue and its transparency could be a response to a more fundamental lack of liquidity. If investors almost never wish to trade their bonds, it may be economically wasteful to maintain the infrastructure to provide continuous price quotations. On the other hand, investors may rarely trade their bonds because information about prices is not available at low cost, or because they know the lack of transparency will put them at an informational disadvantage in negotiating terms of trade.

\subsection{Contemporary Views of the Merits of Alternative Trading Venues}

Even listed bonds have traditionally also been traded over the counter. The trading of Treasury bonds, which historically had occurred on the Exchange, migrated to the OTC dealer market in the twenties. Migration of the trading of corporate bonds occurred later, during the 1940s. This development is illustrated in Figure 1. Panel A plots bond turnover on the NYSE per year. Bond volume peaked in the 1920s and 1930s, fell dramatically in the 1940s, and then rose moderately in the 1960s before tailing off to negligible amounts in recent years. (The increase in the 1960s was largely due to the popularity convertible bonds traded on the exchange enjoyed with retail investors during this period: see our discussion below in Section 7.) Panel B illustrates that relative to the volume in equities, the drop in bond volume in the 1940s was even more dramatic. Bond volume rose to over $30 \%$ of stock volume during the depression years, fell precipitously in the 1940s, and has continued a steady decline since then. Contemporary observers were aware of these trends. As early as 1946, an investments textbook mentioned that:

Prominent among the issues that are traded both on an exchange and over-the-counter are United States Treasury bonds and such instrumentalities as Federal Farm Mortgage Corporations and Home Owners Loan Corporation issues. The volume of trading in these issues, especially Treasury bonds, in the over-the-counter market ordinarily exceeds that on the exchanges. 
(Prime, 1946, page 59.)

A few pages later in the same book, we find, "Stocks are bought and sold primarily through the exchanges; bonds are usually bought and sold over the counter (Prime, 1946, page 65)". Along the same lines, P. Shultz concluded his book with a list of open issues, including the following question, "What is to be done about bond trading, only 10 per cent of which is now done on the exchange and the rest over-the-counter?" (Shultz, 1946)

A book written in the 1950's by an investment banker, noted that:

The major, and often the only, market for state, county, city, town, and village bonds - as well as the increasing number of obligations issued by the so-called authorities - is also the overthe-counter market. ... Corporate bonds - industrial, rail, and utility - are frequently traded over-the-counter even though such issues are listed on an exchange. (Gellermann, 1957, pages 102 and 103).

Contemporary observers show a clear understanding of the relative advantages and disadvantages of exchange and OTC trading for different market paricipants.

In the thirties, it seems to have been recognized that exchange listing was associated with greater liquidity - the ability to trade cheaply and quickly without moving the price. The Confessions of a Bond Salesman, published in 1932, concludes a chapter (page 19) as follows:

He who is likely to need quickly to turn his capital into cash - and what investor is not - should, by all means, buy listed securities, or securities whose market is based upon the listed market.

Even, Lawrence Chamberlain, who was a senior manager of a Bond House, conducting trading in the OTC market, and a vocal advocate of the latter system, writes that, "It is unquestionably true that the average listed bond can be more readily sold or hypothecated than the average unlisted." (Chamberlain, 1925, page 63) On the other hand, Chamberlain described the OTC market as a significant competitor of the exchange, already in the 1920s:

The great system of American bond houses ... is really an immense exchange in itself, reaching out with its branch offices and traveling representatives over the more settled parts of the United States and Canada. This system, with the aid of telegraph and telephone, fulfils for most purposes the legitimate functions of an investment exchange. There is of course no similar system for stocks... So satisfactory is this system of bond-interchange that over 90 per cent of transactions in listed bonds (it is estimated) takes place outside of the exchanges. If one 
wished to buy or sell Peoples' Gas Light and Coke Company Refunding 5s he would probably do slightly better with a well-known Chicago Bond house than on the New York or Chicago exchange. (Chamberlain, 1925, page 66.)

Market participants and observers were also aware that different trading venues were preferable for different types of investors. In his 1946 investment analysis textbook, NYU professor John Prime wrote:

Some securities have certain features that make them especially adaptable to trading in the over-the-counter market. Among those features [is the] eligibility for purchase by banks and insurance companies... Institutional investors such as banks and insurance companies usually buy and sell securities in large blocks... They desire to avoid a public record of large purchases or sales of bonds because of the adverse effect such a transaction may have on the market price of such issues... Furthermore, since a large buying order on the Exchange at a limited price must give precedence to all orders having priority at that price, the institutional order would experience difficulty in completion at the limited price. The over-the-counter-dealer is in a better position to provide this service than the stock exchange broker. (Prime, 1946, page 66.)

In addition, on the OTC market, and especially for large blocks, institutions could negotiate the compensation of the intermediary. In contrast, on the exchange, commissions were regulated, and could not be negotiated. Furthermore, the professionalized management and relatively frequent presence in the market of institutions makes transparency less important to them than to less sophisticated small investors who trade infrequently. The repeated interaction that dealers and institutions have with each other renders them less vulnerable to the opportunities which a lack of transparency affords other participants to profit at their expense on a one-time basis.

Smaller institutions and individuals, for the opposite reasons, will tend to fare better in an exchange-based trading regime. Indeed, the theoretical model of Bernhardt et al (2005) shows that, in a dealer market, large institutions will trade more frequently and in larger amounts than retail investors, and incur lower transactions costs. ${ }^{6}$ Gellerman, who was an investment banker, mentions the disadvantages of this market for small investors:

There is no record of transactions in the over-the-counter market, which puts the individual investor at a strong disadvantage. The professional or institutional investor can transact business with an over-the-counter firm on some basis of equality, but the individual is more or less forced to rely on the integrity of the firm with which it is dealing. Almost all over-the-counter firms are members of the National Association of Securities Dealers, which has regulatory authority

\footnotetext{
${ }^{6}$ Bernhardt et al (2005) also offer an interesting empirical illustration of these effects in the case of the London Stock Exchange.
} 
over its members. NASD has never ruled on what it considers a reasonable profit on a purchase or sale by one of its members, but is known to favor between 3 and 5 per cent. There have been some startling deviations from this policy, however. (Gellermann, 1957, pages 104 and 105.)

\section{Data}

We use aggregate series from various sources to document the broad features of the bond market's evolution, and we supplement this with high-frequency data historical and modern sources.

\subsection{Aggregate Series}

We employ several series to evaluate secular trends in bond financing and the types of investors holding bonds. Hickman (1960) provides data on the total par amount of outstanding corporate bond issues between 1900 and 1944. He also documents which of these issues are listed on the NYSE and which are not. The latter are mostly private issues, traded over-the-counter. Hickman (1960) provides no information on Treasuries or Municipal bonds, however. The NYSE factbook on line ${ }^{7}$ provides rich historical data on the total amount of outstanding bond issues listed on the NYSE, often dating back to the first half of the 20th century. It does not, however, categorize the bonds by type of issuer.

The Federal Reserve Bank ${ }^{8}$ provides yearly time series, dating back to 1944, from the flow of funds statistics. That includes the total amount of outstanding bonds, categorized by type of issuers (Treasury, Municipal, Corporate), as well as information on who holds these bonds. However, it does not document whether these bonds were listed on the NYSE or not. Guthman (1950) provides information on the total amount of bonds outstanding between 1920 and 1948. He categorizes these bonds by issuer type (Treasuries, Corporate, Munis). He also gives information on who held these bonds, but does not document whether the bonds were listed on the NYSE.

Historical data on trading volume is available through the NYSE factbook on line ${ }^{9}$ for bond issues listed on the NYSE, often dating back to the first half of the 20th century. This source does not categorize these bonds by type of issuer. Trading in Treasury bonds, however, migrated off the Exchange in the early twenties, and turnover in municipal bonds has always been much lower than

\footnotetext{
${ }^{7}$ See www.nysedata.com/factbook.

${ }^{8}$ See www.federalreserve.gov/releases/z1/.

${ }^{9}$ See www.nysedata.com/factbook.
} 
in corporate bonds. Thus, from the mid-twenties on, aggregate bond trading volume on the NYSE consists primarily of corporate bonds. There are no historical data available on trading volume in the OTC market. Until very recently, trades conducted over the counter were not compiled in a central source, or reported to the investing public and regulatory authorities.

\subsection{High Frequency Trades \& Quotes}

Throughout the 20th century, the Exchange has been supplying data on all trades and daily quotes to a vendor, Francis Emory Fitch, that compiled and reported it on a daily basis. Data on trades and quotes were also reported, on a weekly basis, in the Commercial EFinancial Chronicle. Both the Francis Emory Fitch and the Commercial \& Financial Chronicle data are available at the NYSE archives.

By examining this data we found that bond trading dried up on the Exchange in the late twenties for municipals and in the mid-forties for corporates. Thus, we manually collected Francis Emory Fitch and Commercial \& Financial Chronicle data on Exchange trades and quotes for municipal bonds from 1926 to 1930 and corporate bonds from 1943 to 1948. These sample periods bracket the periods during which bond trading migrated from the NYSE to the OTC market, and thus allow us to observe periods of both high and low liquidity.

Francis Emory Fitch reports the following data for each transaction: the trading day, the transaction price and the quantity traded. It also states whether the trade took place between 10:00 a.m and 12:00 noon, 12:00 noon and 2:00 p.m, or 2:00 p.m and 4:00 p.m. Francis Emory Fitch also reports the bid and ask quotes observed at 11:00 a.m. The Commercial \& Financial Chronicle reports quotes as well as the highest and lowest transaction price during the week and the total quantity traded that week. On weeks without trades, the Chronicle reported the price and month of the last trade.

Through the 1920s the NYSE made a market in sixteen long-term New York City municipal bonds. New York municipals were at that time, and still are, among the most actively traded municipal bonds. All the bonds had initially been issued with a maturity of 50 years. We collected data for a representative sub-sample of 6 municipal bonds, during 292 trading days from 1926 to 1930. From July 1, 1926 to December 31, 1927 and from July 1, 1928 to March 31, 1930, 
we collected data from Francis Emory Fitch on each and every trade conducted on the Exchange in these 6 bonds. The Francis Emory Fitch data was unfortunately not available at the NYSE Archives for the first 6 months of 1928. For that period, we relied only on the Commercial $\&$ Financial Chronicle. Thus for that subperiod, we observe only the highest and lowest price and total traded quantity. For the large majority of the weeks, this is not a limitation, however, as there is no more than one trade per week. For the periods for which both data sources are available, we checked that the data reported by the Commercial \&5 Financial Chronicle were consistent with those reported by Francis Emory Fitch. For the first year of the sample (July 1, 1926 to June 30, 1927), we have also collected the bid and ask quotes on days without transactions. To illustrate the nature of this data, Figure 2 plots the time series of bid and ask quotes and transactions prices from July 1, 1926 to June 30, 1927 for one the six New York City municipal bonds in our sample.

The majority of trades in bonds on the Exchange occurred at the best quotes or between them. The latter case corresponds to the situation where the brokers of the buyer and the seller meet on the floor and agree on a transaction price within the quotes. In that case, the price impact (defined as the absolute value of the difference between the transaction price and the mid-quote, divided by the latter) is lower than half the spread. There are also some trades outside of the best quotes. In a limit-order book, trading away from the best quotes arises naturally when the size of the trade exceeds the depth at the quotes, and the order walks up or down the book. It can also occur when the quoted spreads, which are recorded at 11 a.m. each morning, become stale. For the corporate bonds in our sample, $77 \%$ of the trades occur within the quoted spread for that day. The municipals trade within the recorded spread $88 \%$ of the time.

We collected trades and quotes from Francis Emory Fitch for 6 corporate bonds from the beginning 1943 to the end of 1947. Three of these bonds were railroad bonds, B\&O Railroads, Great Northern Railroads, and Hudson \& Manhattan Railroads. Railroad bonds accounted for a large share of the trading activity in the market. The remaining three bonds were issued by American Tobacco, Firestone Rubber, and Saguenay Power. We picked these six bonds because we found that trades and quotes data were available for them throughout our sample period. Thus, while our sample is small, it contains bonds that are typical of the market at that time. The highfrequency corporate bond data includes 19,049 transactions, and bid-ask quotes for 8,284 bond-day 
pairs. Close to half (45\%) of the trades are for one or for two bonds, with par value $\$ 1,000$, but we have trades as large as 200 and 300 bonds in American Tobacco during 1943. From 1943 to 2003 the CPI increased by 10.6 times, so a $\$ 300$ thousand dollar trade corresponds to over $\$ 3$ million today.

The data were originally manually recorded, and not surprisingly contain many obvious clerical

errors. We eliminated from our sample bond-days where one side of the bid-ask spread was missing, where the quoted spread was negative or exceeded $50 \%$ of the price. In a small number of cases we corrected transcription errors where a decimal was misplaced or the bid and ask price were inverted, if it were obvious from the surrounding prices and quotes that such an error had been made.

One of our goals is to compare the costs of trading bonds today, in the OTC market, to the costs of trading bonds historically on the exchange. To make this comparison for corporate bonds we rely on summary statistics from modern studies of trading costs that in turn rely on the TRACE data base. For municipal bonds a sample of trades in 39 modern bonds was gathered from the web site "Investinbonds.com." This web site reports historical transactions in municipal bonds gathered by the Municipal Securities Rule Making Board (MSRB), and combines these transactions data with information on the bonds, such as credit ratings, obtained from other data vendors. The MSRB began requiring all registered broker dealers to report transactions in municipal bonds to them beginning in May of 2000. The data was initially made available to the public with a 30-day lag, unless the bond traded more than four times in a day, in which case it was reported with a one-day lag. Through a series of steps, the MSRB has moved to more timely reporting, until currently transactions are reported 15 minutes after they are executed. The MSRB data identify trades as customer purchases, customer sales, or interdealer trades.

\section{Why Has Bond Volume on the Exchange Decreased?}

In this section we examine some of the explanations that have been advanced for the demise of exchange-based bond trading. 


\subsection{Trends in Bond Financing}

The decline in bond trading on the exchange has occurred despite broad increases in the supply of bonds outstanding in all sectors. Figure 3 combines data from different sources (Guthman, 1950, Hickman, 1960 and The Flow of Funds compiled by the Federal Reserve Bank) to show increases in par value outstanding from 1920 to 2002 for treasury, municipal, and corporate bonds. To ensure comparability all the figures are in 2002 dollars, using the Consumer Price Index. There is a steady geometric increase in corporate bonds outstanding (in real terms), reflecting economy-wide growth in economic activity and new investment in the corporate sector. ${ }^{10}$ Both municipal and federal debt show more variable growth rates, reflecting the cycles in government surpluses and deficits. Treasury debt jumped dramatically in the early 1940s to finance the war effort. Both municipal and federal debt decreased in real terms slightly in the 1990s because of government surpluses.

Comparing Figure 3 to Figure 1, it is clear that changes in trading volume on the Exchange are not explained by changes in the supply of bonds. There is no evidence of a drop in debt financing in the 1940s, which was the period when the drop in volume is most striking. Bond trading volume on the Exchange largely disappeared in the 1980s and 1990s. Yet this was a period when U.S. corporations made net substitutions of debt for equity, as shown, for example, in Rajan and Zingales (1995). Debt outstanding grew by more than net new investment, because firms financed repurchases of shares with debt.

\subsection{Regulatory and Disclosure Costs}

Could bond trading have dropped on the exchange in the 1940s because bond listings declined, in response to the regulatory requirements associated with New Deal security legislation? ${ }^{11}$ The Securities Act of 1933, which is concerned with the initial distribution of securities, requires that securities offered to the public must be registered with the SEC. The registration statement must contain specific information about the security, the issuer, and the underwriters. The Securities Exchange Act of 1934, which is concerned with secondary trading, states that no security may be

\footnotetext{
${ }^{10}$ This increase also reflects the financial choices of US corporations in the 2 postwar decades, during which debt increased from 15 to $30 \%$ of corporate financing, while the use of equity declined from 5 to $2 \%$ of corporate financing (see White, 2000, page 777).

${ }^{11}$ For a description of this regulatory framework, see Loss and Seligman, 1998, in particular Volume I, pages 225 and 226. See also White, 2000.
} 
listed on an exchange unless its issuer files an application for registration containing much the same information as is required by the 1933 Act. This information must be kept current by the filing of annual and other reports with the exchange and the SEC. Securities that are not listed on an exchange are not subject to these provisions. The regulatory burden associated with public trading and exchange listing may have encouraged their private placement and led to a decrease in trading volume on the exchange.

In light of this hypothesis, consider Figure 4, which plots the time series of the number of bond issues listed on the NYSE between 1925 and 2003. ${ }^{12}$ To shed some light on the relation between this variable and trading volume on the exchange, we also plot on the same graph the time series of bond trading volume on the NYSE. The trading volume figures are expressed in 2003 dollars, using the Consumer Price index. Figure 4 shows no evident association between the bond volume and bond listings on the exchange. Bond trading volume was at its peak in the mid 1930s, when the number of bonds listed was slightly lower than 1600. The number of bonds listed was at its peak in 1986, with 3856 issues listed, and yet bond trading volume on the exchange was very limited at this point in time. It seems implausible, then, to attribute the drop in bond trading volume on the Exchange to increased listing costs associated with the New Deal securities legislation.

\subsection{The balance of trading clienteles}

Liquidity attracts liquidity. There are obvious positive externalities in trading. Once a trading venue becomes a focal point for trading, it is difficult to move trading elsewhere because of the coordination problems involved. The first defectors from the status quo will have no one to trade with, unless they can bring large numbers of other participants with them. Furthermore, large traders and small traders need each other. The trades of institutions and dealers contribute to make prices informationally efficient. And large professional traders need small liquidity traders to absorb the positions they are unwinding. Thus, there are forces that will lead traders of different types to cluster in the same market, as shown by Admati and Pfleiderer (1988).

Over-the-counter and exchange-based bond trading coexisted for decades in the 20th century with viable levels of activity in each setting. What upset this balance? Was the migration to the

\footnotetext{
${ }^{12}$ This series was obtained from the NYSE factbook on line: www.nysedata.com/factbook.
} 
OTC market triggered by changes in the structure of the population of bond investors? Combining Guthman (1950) and data from the Fed, we present in Figure 5 the evolution of bond ownership between 1920 and 2004. ${ }^{13}$ As can be seen in Panel A, there was a dramatic increase in institutional ownership in corporate bonds between 1940 and 1960. In the 1940s the weight and importance of institutional investors in the bond market grew tremendously. These investors came to amount for the majority of the trading activity in the bond market. Naturally, they chose to direct their trades to the OTC market, where they could effectively exploit their bargaining power, without being hindered by reporting and price priority constraints, and where they could avoid the regulated commissions which prevailed on the Exchange. Thus, the liquidity of the corporate bond market migrated to the dealer market.

\section{Municipal Bond Trading and Trading Costs in the 1920s}

Trading in municipals on the NYSE collapsed at the beginning of 1929. Figure 6, Panel A, displays monthly trading volume on the NYSE for the six NYC municipal bonds, measured in number of lots traded. Panel B plots the average price impact of trades. The market was quite active, and price impact rather low in 1926 and 1927 (below 50 basis points). Towards the end of the period, however, liquidity, whether measured by the cost of trading or the amount of trading, collapsed in a remarkably short period of time. As can be seen in Panel A, volume collapsed in February 1929. Panel B shows that price impact had been rising since August 1928. While it had remained below $0.5 \%$ until July, it approached 1\% in August. After February, it ranged between $1.5 \%$ and 2.5\%. Through March of 1930, Francis Emory Fitch continued to report some quotes for Municipal bonds, and a few rare trades. After April of 1930, liquidity had permanently vanished. Francis Emory Fitch had no longer any quote or trade data to report for municipal bonds. We verified that this continued through the end of the decade. In January 1933, October 1936, and October 1939, for example, there were no trades and no quotes whatsoever. Thus trading in municipal bonds disappeared on the Exchange long before corporate bond trading declined. Why such a sudden

\footnotetext{
${ }^{13}$ The fraction of the bonds owned by different categories of investors is depicted on the vertical axis. For the period before 1945, we only have the total amount and the amount owned by insurance companies, banks and savings institutions. For the period following 1945, we have data on all categories of owners. The percentages on the figure do not add up to one because we have not depicted certain categories of investors. For example, foreign corporate bond ownership, which has become important in the recent years, is not depicted in the figure.
} 
collapse? Municipal bond volume migrated off the exchange because of a convergence of factors, which now we examine in turn.

First, the surge in stock trading in the late 1920s raised the profits of members but strained capacity. Bond volume on the exchange was flat in the 1920s, in contrast to stock volume. Figure 7 uses data published January 3, 1929 in the Wall Street Journal, and shows bond volume (par value), stock volume (shares traded) and exchange seat prices (midpoint between the high and low dollar values). Each series is normalized by its value in 1890, to emphasize the relative growth rates. Prior to 1920, bond volume and stock volume trended upward together, along with seat prices. For example, from 1918 to 1919 all three roughly doubled. Bond volume peaked in 1922, but stock volume shot up dramatically in the boom of the late 1920s.

The increase in stock trading activity raised the profits of the members of the Exchange. Figure 7 shows that seat prices (which reflect the expectation of the capitalized profits of the members) tend to follow stock volume, when growth in stock volume and bond volume depart. The marginal seat price was, apparently, driven by activity in stocks, not bonds. A regression of the percentage change in the normalized seat price against percentage changes in normalized bond and stock volumes yields an adjusted R2 of $43 \%$. The coefficient of stock volume is significantly positive with a t-statistic of 5.28, while that of bond volume is not significantly different from 0 . Given the strong public demand for investing in stocks, and the commission rates described in Section II, stock trading was more profitable for brokers than bond trading. While the increase in stock trading activity raised the profits of members, it also strained capacity. An article in the Wall Street Journal from 1929 states:

Since the speculative phase in stocks set in April, last, the physical and mechanical facilities of the Exchange have been taxed to capacity and, notwithstanding many improvements made for faster service, the ticker service during many sessions proved to be unable to keep abreast of the actual sales made on the floor, especially during the 2,000,000 and 3,000,000 share days. (January 3, p. 31)

Davis, Neal and White (2005) chronicle the exchange's attempts to increase capacity in response to the dramatic increases in volume. On several days during 1928, the exchange had to close following a day of unprecedented trading volume. It eventually declared a quarter-seat dividend to all existing members, in order to increase the number of seats available and thus the number of 
people allowed to trade on the floor.

Second, in response to these capacity problems the Exchange allocated trading capacity away from bonds and towards equities. The reallocation of resources to stocks is reflected in the minutes of the Committee on Arrangements of the NYSE through the early part of 1929. In the minutes of January 3, for example, the committee approved "allowing Arthur E. French \& Co. to have a telephone space in sections WA and WB in the bond crowd, for stock business." The committee approved a similar proposal for another member firm on January 8, and also referred to two individual members the "matter of removing the Inactive Stock Crowd to the bond room." In the January 15 meeting, one of those individuals, M. Mills, "reported progress with reference to the location of post 30 in the bond room." There then follows, in February and March, a series of approvals of changes of location, moving 16 individual preferred stocks and two common stocks to Post 30 from other posts. Examples of these entries are: March 26, "Request of Arthur A. Zucker to move Filene's sons company 6\% cumulative preferred to post 30, effective April 1, 1929, was approved." April 2, "The committee approved the request ... that the Common Stock of the Nickel's Holding Corporation be moved from post 14 to post 30." These changes involved costly adjustments to infrastructure, and so were not trivial decisions. On March 12, for example, the minutes report: "The committee directed that Post 30 be removed to the Southerly Bond Crowd Room as soon as a separate tube station relay can be provided...As soon as post 30 is moved, telephone booths are to be placed in the space now occupied by that post."

A third factor was that in the late 1920s institutions became relatively more important than retail investors in municipal bonds. As retail investors were attracted by the dramatic appreciation in equities, they lost interest in less exciting securities, which they had held traditionally, such as municipal bonds. The New York Times states in late January, 1929:

Since municipalities in various parts of the country have found, to their chagrin, that they cannot borrow at nearly as advantageous rates this year as last, the charge is made in many quarters that the stock market is directly responsible. In other words, an investor will not take a municipal bond at 4 per cent if he sees an opportunity to double his money in the stock market. (NYT, Jan. 31, 1929, "Topics in Wall Street," p. 29.)

This left institutions as the major players in the municipal market. For example, near the end of January 1929 the New York Times reported, "There were probably fewer municipal bonds sold at 
retail this week than in any week since December. Insurance companies and institutions did what little buying was noted." (NYT, Jan. 26, 1929, “\$21,488,121 Sought by Municipalities.”) In early February the Times stated:

The municipal bond market this week has been extremely quiet, though most of the new offerings have been fairly well received. Institutions continue to furnish most of the buying power, and, in addition to the new offerings, have been called upon to absorb various blocks of old issues which have been brought out of retirement. (NYT, Feb. 2, 1929, "58 Loans Sought by Municipalities," p. 27.)

As discussed above, while retail investors tend to be hurt by OTC trading, institutions can benefit from it. Hence, the investors active in municipal bonds in the late 1920s were naturally attracted by the OTC market.

These several factors - booming demand for high margin stock trading services, flat demand for lower margin bond trading services, waning interest in municipal bonds from the retail clienteles which the Exchange serves best, and reduction by the Exchange of the resources available for bond trading - combine to provide a circumstantial case that Exchange trading in municipal bonds dried up in early 1929 because floor traders had more profitable activities to pursue and institutions, which had become the main players in this market, naturally gravitated to OTC trading. As it turned out, of course, the boom in equity volume was short-lived. Yet municipal bond volume never returned to the Exchange. This irreversibility is not surprising, due to the positive externalities associated with liquidity, and the coordination problems in moving volume from one venue to another. Concerned with the competition of the OTC market, in the mid 1930s the Exchange introduced the "nine bond rule":

The Committee has recently ruled that members must seek a market on the Exchange in certain bonds before executing orders for less than 10 bonds elsewhere. This rule is likewise intended to give the public the full benefit of the existing market and it is hoped that eventually it will result in bringing to the Exchange a larger portion of the business in listed bonds which is now done over the counter. (New York Stock Exchange Committee on Bonds: Report to the Governing Committee. May 12, 1936).

While this rule may have had some effect in corporate bonds, it did not result in a revival of municipals trading on the Exchange.

Next, we compare the costs of trading municipal bonds at a time when they traded actively on 
the NYSE with their recent counterparts in dealer markets. All the bonds in the historical sample are New York City municipals. These were, and still are, among the most liquid bonds in the municipal market. All six of these bonds were "seasoned" during the sample period. They had all been issued more than ten years previously. They were all very long maturity, having been issued with a maturity of 50 years. Tables 2 and 3 report descriptive information and summary statistics for our historical sample of municipal bonds while Table 4 reports similar statistics for modern New York municipal bonds. New York bonds are among the most liquid municipal bonds in the modern market for several reasons. Because New York has high state income taxes, and only New York issues qualify as tax-exempt for New York state income tax, New York residents understandably favor New York bonds. The state also has many high-income residents, with high marginal tax rates, who are attracted to municipals. It is also a state with a large population. Thus, the bonds in Table 4 trade relatively frequently when compared to the population of municipal bonds. The modern environment does not offer a set of municipal bonds with maturities as long as the bonds from the 1920s. Municipal bonds today are typically issued "in series." A single underwriting includes a range of maturities up to 20-30 years. Most long-term municipals are also callable. Therefore, by the time most of the bonds have five to ten years of seasoning, they are often close to their call date. All the bonds we have selected have more than five years of seasoning. Nevertheless, it is obvious from inspection of the table that the modern bonds typically trade with greater frequency and in larger volumes than did the New York City bonds during 1926-1928.

For the modern sample, we do not have quoted spreads. Trading is quite infrequent, however, and most trades can be matched with offsetting transactions that clear dealer inventories. Trades in seasoned bonds are usually initiated with a sale by a customer to a dealer. We select all customer sales followed by customer purchases that add up in par value to the initial sale, with no intervening transactions. Our measure of trading cost is the realized "dealer markup," the percentage return earned by the dealer on the round-trip transaction. Green, Hollifield, and Schürhoff (2007a) apply other trade matching methods, such as a first-in-first-out rule, and find that they yield similar measure of trading costs. Harris and Pirowar (2006) use time-series methods to estimate effective spreads for the bonds that experienced more than four trades during their sample period, and also find measures of trading cost that average between $1.5 \%$ and $2.0 \%$ for retail trades. 
Both Green, Hollifield, and Schürhoff (2007a) and Harris and Pirowar (2006) show that trading costs for bonds in the OTC markets fall dramatically with trade size. Edwards, Harris, and Piwowar (2007) and Goldstein, Hotchkiss, and Sirri (2007) show this also holds for corporate bonds. As Table 3 shows, the relation between trade size and percentage price impact is relatively flat for the historical sample. In the next section, we will see that corporate bonds in the 1940s exhibit similar behavior. Since commissions for municipal bonds were negotiable in the 1920s, they may have exhibited some discount for large quantities, which would render total trading costs decreasing in trade size. This behavior contrasts with modern limit-order markets for equities, in which price impact has been shown to increase in trade size. ${ }^{14}$

There is cross-sectional variation in the measures of trading cost within both the modern and historical samples of municipal bonds, and the costs of trading appear correlated with trading frequency and volume. Comparison of Tables 2 and 4, however, reveal that average trading costs are almost uniformly lower in the historical sample. The average dealer markup across all the bonds in the modern sample is $2.45 \%$. Note that this average includes both retail- and institutional-sized trades. For the municipals trading on the NYSE in 1926-1928, the average percentage bid-ask spread was $0.59 \%$. The average price impact was $0.246 \%$. As discussed earlier, traders had to pay commissions on the exchange. A generous estimate of the magnitude for a commission would be $\$ 2$ for a $\$ 1000$ trade. Even after adding the corresponding round-trip commission of $0.4 \%$ to the average bid-ask spread, our findings suggest that transactions costs for retail investors in the municipal bond market in the 1920s were less than half what they are now. Our sample of modern municipals are very seasoned, and hence may have higher costs associated with them than other bonds. Harris and Piwowar (2006) find that effective spreads in the municipal bond market average 2 percent for retail size trades. It is also striking that on dimensions other than cost, the modern sample appears more "liquid." The vast majority of the bonds trade with greater frequency, and with much higher par volumes than the bonds in the historical sample. Finally note that the greater transactions costs observed in the contemporary bond sample cannot reflect greater default risk. Indeed, all the contemporary bonds in our sample are insured or AAA.

To gain a better sense of the patterns of transactions costs and trading activity in the historical

\footnotetext{
${ }^{14}$ See Biais, Glosten, and Spatt (2005), section 1.2, for a survey of this evidence.
} 
and contemporary samples, we ran the following cross-sectional regression using the averages for the modern sample reported in Table 4:

$$
(\text { Mean markup })_{i}=b_{0}+b_{1}(\text { Mean days with trade })_{i}+b_{2}(\text { Mean yearly volume })_{i}+e_{i}
$$

where $i=1, \ldots, 39$ indicates the bond. Using the fitted values of $b_{0}=2.615(t=13.822)$, $b_{1}=-0.0122(t=-2.040)$ and $b_{2}=0.0007(t=2.274)$, we predict the mean markup on a modern bond with the same annual trading frequency and volume as the bonds trading in 1926-1927. The volume is adjusted to the 2003 price level. Table 3 displays the resulting fitted values for the trading markup for each bond, along with the difference between it and the average bid-ask spread plus round trip commission on the NYSE. The average difference is $-1.37 \%$. The average fitted value based on the modern data is 2.4 times higher than the average trading costs in 1926-1927. Clearly, since we regress prices on quantities, this cannot be interpreted structurally, or in terms of causality. It does, however, reinforce the view that the patterns of transactions costs and trading activity are very different in the contemporary and historical samples.

Large transactions costs for retail traders in the municipal bond market have a significant impact on investors welfare since, because municipal bonds are mostly held by individual investors, as can be seen in Figure 5, Panel B. Individuals' share of municipal bond holdings did not decrease throughout the century. The tax-exempt status of municipal bonds makes them relatively attractive for individual investors, and tax rates rose over the course of the century, from the imposition of the income tax in the Wilson administration, through the New Deal and WWII, until they began to fall in the $1980 \mathrm{~s}^{15}$

\footnotetext{
${ }^{15}$ While individuals have always had an important presence in the municipal market, the figure shows the composition of institutional holders changed dramatically in the 1980s. The share of municipals held by banks dropped dramatically, while that of mutual funds rose to offset this drop. This reflects changes in the tax law that limited the ability of commercial banks to deduct interest liabilities used to finance holdings of municipals. (See Feldstein, Fabozzi, and Fabozzi (1995), p. 178.) The ability to engage in this quasi-tax-arbitrage obviously made municipal bonds especially attractive to banks. Mutual funds, in contrast, simply pass the tax-exempt treatment of the bonds through to the mutual-fund shareholder.
} 


\section{Corporate Bond Trading and Trading Costs in the 1940s}

Figure 1 shows that bond trading activity dropped on the Exchange in the mid-forties. Our highfrequency data enables us to provide a more detailed picture of this drop. Table 6 shows the number of trades and average trade size on the NYSE by year for the six corporate issues in our sample. In 1943 and 1944, trading activity was relatively high. There were around 800 trades per bond issue each year, which is over two transactions per trading day. The trading frequency observed in the modern OTC corporate bond market has been documented in modern studies. Using TRACE data Goldstein, Hotchkiss and Sirri (2007) observe on average 1.1 trade per day, and Edwards, Harris and Piwowar (2007) around 2.0 trades per day. While our historical sample is far from comprehensive, this suggests that in terms of number of trades, the limit-order book on the NYSE was able to support volumes in excess of those for modern OTC bond markets. From 1945 on trading activity declined, but this behavior was not uniform across bonds. The decrease in number of trades was not offset by increases in trade size. Average trade size decreased steadily throughout the sample period. It appears the drop in liquidity, while quite evident, was not as sudden or dramatic as that which occurred for municipal trading in the 1920s.

In Table 7 we report average percentage quoted bid-ask spreads by year and average percentage price impact by year and trade size for the corporate bonds in our sample. The percentage quoted spreads show a clear tendency to increase across years, and are particularly high in 1947. This tendency is also evident in the price impact, though with less uniformity across bonds. Price impact appears flat or increasing in trade size for most bonds. In Table 8 we report mean and median price impact across all bonds in our sample, stratified by trade size (columns 3 and 4 ). Price impact appears to be flat across trades of different sizes.

To measure total transactions costs, commissions must be added to price impact. For each transaction in our data set, we computed the commission using the top panel of Table 1, "business

for non-members." Since commissions are larger, on average, than market impact, and since they fall with trade size, the total transaction costs fall with trade size. In Table 8 we also report total one-way costs for trades in our data set of a fixed size. Trading costs decline initially, but quickly level off in size.

The one-way costs for retail-sized trades are similar in magnitude to estimates from modern 
data, but they are higher for large trades. For example, Edwards, Harris, and Piwowar (2007) report $^{16}$ estimates of mean (median) one-way costs of 75 (60) basis points for trades of $\$ 5,000$ and of 71 (56) for trades of $\$ 10,000$ par value. Their sample includes all 21,973 TRACE bonds from January 2003 to January of 2005. The estimated costs decline steadily with trade size to less than five basis points for trades of over $\$ 2$ million. Goldstein, Hotchkiss, and Sirri (2007) study 4,888 BBB bonds from July 2002 to February 2004, and estimate mean (median) one-way costs of 118 (113) basis points for trades involving less than $\$ 10$ thousand and 109 (100) basis points for trades between $\$ 11$ and $\$ 20$ thousand. The average costs then fall to 25 (15) basis points for trades in excess of $\$ 1$ million. ${ }^{17}$ The average trading costs in our sample are between those reported by these two papers for small trades, and fall by less as trade size grows. Thus, despite the relatively high commissions prevailing in the 1940s, and the stress the corporate bond market was under at the time, trading costs for retail investors were roughly as low as they are in today's bond market.

To better understand the relationship between trade size and trading costs, in Table 9 we report regressions, with and without bond-specific fixed effects. The regressors are days from January 1, 1943 and the natural log of trade size. In the first two columns of the table, the dependent variable is the price impact as a fraction of the midpoint, measured in basis points, and in the last two columns the dependent variable is total one-way cost. Price impact increases in both trade size and time. The total cost is also increasing with time, and decreases modestly with trade size. These results are quite robust to controlling for heterogeneity across bonds through fixed effects.

The relationship between trading costs and trade size is much flatter in the historical exchange data than in the modern samples. This could reflect cross subsidization from large traders to small traders historically, or from small to large traders in the contemporary environment. It could also reflect changes in the relative costs to intermediaries of servicing these different types of trades. Note that Bernhardt et al (2005) also find that transactions costs decreased with size for equities on the London Stock Exchange when the latter operated as a dealer market. This set of results from different markets suggests that it may be the structure of the market, not the type of security traded, which determines if price impact increases or decreases with trade size. In dealer markets,

\footnotetext{
${ }^{16}$ See Table IV in Edwards, Harris, and Piwowar (2007)

${ }^{17}$ See Panel C of Table 6 in Goldstein, Hotchkiss, and Sirri (2007). The table report round-trip rather than one-way costs.
} 
price impact is smaller for large trades, perhaps because in fragmented markets large traders have enough bargaining power to obtain better trading terms. In limit-order markets, price impact for larger trades may reflect inventory risk and adverse selection making such trades costly for liquidity suppliers.

What is most puzzling, in our view, is that costs in the modern data are as high as they are relative to the historical costs. The underlying costs to the intermediating institutions are costs of identifying and matching counter parties (communication costs) and of managing and tracking inventory and orders (data-processing costs). In other sectors of the economy these costs have fallen dramatically due to technological progress.

\title{
7 Convertible Bonds and Stocks
}

A relatively recent example of migration from the Exchange to the OTC market is offered by the convertible bond market. As can be seen in Figure 1, Panel A, and in Figure 4, there was a modest revival of the NYSE bond market in the late 1960s. This was due to the rise of the convertible market, and the interest that retail investors took in this market. ${ }^{18}$ An early indication of this evolution is given in the 1967 NYSE fact book (page 14):

\begin{abstract}
Bond volume on the exchange in 1966 was the highest since $1943 \ldots$ the 50 bonds with the largest volume accounted for $65 \%$ of the of the activity... Among the 50 most active bonds, 42 were either convertible bonds or bonds maturing within a year or so... Convertible bonds are exempt from the FRB margin requirements at banks and, when selling above the conversion price, rise and fall with the stock into which they are convertible. Thus, these bonds have more appeal to individual traders and investors than do straight corporate bonds.
\end{abstract}

Volume in bonds during 1967 was higher yet. As mentioned on page 15 in the NYSE fact book for that year, convertible bonds amounted to $63 \%$ of all the bond trading volume. The next years continued to see high bond trading volume on the Exchange, and significant retail activity. For example, the 1972 fact book notes, on page 17: "Individual investors continued to be attracted to the bond market in 1971." And a few sentences later: "Of the 50 leading bonds, 32 were convertible issues, the same number as in 1970." Then, as can be seen in Figures 1 and 4, bond trading on the Exchange declined again. As was explained to us by a bond broker who operated in that market

\footnotetext{
${ }^{18}$ Unlike the other segments of the bond market, trading in convertible bonds remained floor-based even after 1976.
} 
at the time, as the market for convertibles matured, it became dominated by large institutions. The latter chose to direct their orders to the OTC market, and liquidity migrated away from the Exchange. Correspondingly, in 1973, the NYSE fact book, noted, on page 17, that: "individual investor's participation in the bond market diminished." This anecdotal evidence is consistent with our argument that when the weight of institutions reaches a critical point, small traders are forced to follow large traders to the OTC venue.

An obvious question is why exchange trading remained predominant in the stock market, in such a stark contrast with the bond market. One important difference between bond and stock trading on the Exchange is that, while the bond market has always been purely order driven, specialists have traditionally supplied liquidity in the stock market. It is possible that the presence of the specialist anchored the liquidity on the exchange. Because it was common knowledge that the specialist would be there to supply liquidity, small and medium sized trades could continue to be directed to the exchange. Because liquidity attracts liquidity, the larger traders also found it attractive to trade there, in line with the logic of Admati and Pfleiderer (1988).

Our arguments in previous sections also suggest that exchange-based trading was to be expected as long as small investors played an important role in the market. Consistent with this prediction, the rise of institutional investors was weaker and more delayed in the stock market than in the bond market. In the bond market it took place in the 1930s and the 1940s, while in the stock market it only started in the second half of the 1950s. Quite remarkably, this is when the Exchange introduced Rule 394 (later Rule 390), which prohibited NYSE members from trading NYSE listed securities away from the Exchange. As noted by White (2000, page 784): "The NYSE specialists lobbied their exchange to adopt Rule 394 in 1955 to prevent commission houses from abandoning the floor of the exchange for telephones."

\section{Conclusions}

When several trading venues are available there will typically be multiple equilibria in the allocation of trades. When the investors expect that one market venue will attract all or most orders, they direct their own orders to that market, thus confirming the initial expectation. Hence, liquidity may not gravitate to the most efficient trading venue, and market forces may fail to correct this 
inefficiency, even in the long term. The history of the bond market in the US in the 20th century offers an interesting illustration of these tensions. Bond trading was quite active on the NYSE until the 1940s. Then it collapsed as trading migrated to the OTC market. This was not due to a decline in the role of bond financing in the economy or to a drop in the number of listings. The migration of liquidity happened at times when large institutions became more important in the bond market. This migration appears to have significantly increased transactions cost for retail investors. We estimate that these costs in the recent period are greater than they were in the 1920s and comparable to those prevailing in the 1940s. Given the evident decrease in communication and processing costs in the intervening years, this appears anomalous. 


\section{REFERENCES}

Admati, A., Peiderer, P., 1988, "A theory of intraday patterns: Volume and price variability." Review of Financial Studies 1, 3-40.

Anonymous, 1932, Confessions of a Bond Salesman, Early Publishing Co, Pittsburgh, PA.

Bernhardt, D., V. Dvoracek, E. Hughson, and I. Werner, 20045, "Why do large orders receive discounts on the London Stock Exchange?" Review of Financial Studies 18, 1343-1368.

Bessembinder, H., W. Maxwell, and K. Venkataraman, 2007, "Market transparency, liquidity externalities, and institutional trading costs in corporate bonds," Journal of Financial Economics $82,251-288$.

Biais, B., L. Gosten, and S. Spatt, 2005, "Market microstructure: A survey of microfoundations, empirical results, and policy implications," Journal of Financial Markets 8, 111-264.

Chamberlain, L., 1925, The principles of bond investment, Henry Holt and Company, New York.

Dammon, R., C. Spatt and H. Zhang, 2004, "Optimal asset location and allocation with taxable and tax-deferred investing," Journal of Finance 59, 999-1037.

Davis, L., L. Neal and E. White, 2005, "The highest price ever: The great NYSE seat sale of 19281929, and capacity constraints," Working paper, National Bureau of Economic Research.

Edwards, Amy K., Lawrence Harris, and Michael S. Piwowar, 2007, Corporate bond market transparency and transactions costs, Journal of Finance 62, 1421-1452.

Felstein, S. G., Fabozzi, F. J., and Fabozzi, T. D., 1995, "Municipal bonds," in The Handbook of Fixed Income Securities, 4th edition, Fabozzi, F.J. and Fabozzi, T. D., Editors. Irwin Professional Publishing, New York, pp. 155-185.

Gellermann, H., 1957, How to Make Money Make Money: Professional Advice About Stocks and Bonds, Thomas Y. Crowell Company, New York. 
Goldstein, Michael A., Edith S. Hotchkiss, and Erik R. Sirri, 2007, Transparency and liquidity: A controlled experiment on corporate bonds, Review of Financial Studies 20, 235-273.

Green, Richard C., Burton Hollifield, and Norman Schürhoff, 2007a, Financial intermediation and costs of trading in an opaque market, Review of Financial Studies 20, 275-314.

Green, Richard C., Burton Hollifield, and Norman Schürhoff, 2007b, Dealer intermediation and price behavior in the aftermarket for new bond issues, Journal of Financial Economics, Forthcoming.

Guthmann, H., 1950, "The movement of debt to institutions and its implications for the interest rate," The Journal of Finance, 5, 70-87.

Harris, Lawrence, and Michael S. Piwowar, 2006, Secondary trading costs in the municipal bond market, Journal of Finance 61, 1361-1397.

Hickman, W. B., 1960, Statistical measures of corporate bond financing since 1900, National Bureau of Economic Research, Princeton.

Holland, D., 1958, The Income-Tax Burden on Stockholders. NBER, Princeton University Press, Princeton.

Kemmerer, D., 1952, "American financial institutions: The marketing of securities, 1930-1952." Journal of Economic History, 4, 454-468.

Loss, L., and J. Seligman, 1998, Securities Regulation, Aspen Law and Business, New York.

Mende, A., L. Menkhoff, and C. L. Osler, 2004, "Asymmetric Information and the Cross-Section of Currency Spreads," working paper, Brandeis University.

Meltzer, A. and G. von der Linde, 1960, "A study of the dealer market for Federal Government securities," Materials prepared for the Joint Economic Committee, Congress of the United States, Washington.

Pagano, M., 1989, "Trading volume and asset liquidity," Quarterly Journal of Economics 104, $255-276$. 
Prime, J., 1946, Investment Analysis. Prentice-Hall, New York.

Rajan, R., and L. Zingales, 1995, "What do we know about capital structure?: Some evidence from international data." Journal of Finance, 50, 1421-1460.

Rajan, R., and L. Zingales, 2003, "The great reversals: The politics of financial development in the twentieth century." Journal of Financial Economics, 69, pages 5-50.

Shultz, B., 1946, The Securities Market and How It Works, Harper Bros Publishers, New York.

United States Treasury and Federal Reserve Board, 1959, "Treasury-Federal Reserve Study of the Government Securities Market."

White, E., 2000, "Banking and finance in the twentieth century." In The Cambridge Economic History of the United States, Volume III. Edited by S. Engerman and R. Gallman. Cambridge University Press. 
Table 1: Commission SCHEdule On BONDS, 1943-1947.

The body of the table contains minimum commissions per $\$ 1,000$ of par value on corporate bonds.

\begin{tabular}{lrrrr}
\hline Price per $\$ 100$ par & 1 or 2 bonds & 3 bonds & 4 bonds & $>5$ bonds \\
\hline For non-members, allied members & & & \\
$<\$ 10$ & $\$ 1.50$ & $\$ 1.20$ & $\$ 0.90$ & $\$ 0.75$ \\
$\leq \$ 10<\$ 100$ & 2.50 & 2.00 & 1.50 & 1.25 \\
$>\$ 100$ & 5.00 & 4.00 & 3.00 & 2.50 \\
\hline \multicolumn{5}{c}{} \\
\hline \multicolumn{5}{l}{ For members, no principal given up } \\
$<\$ 10$ & $\$ 0.800$ & $\$ 0.700$ & $\$ 0.600$ & $\$ 0.500$ \\
$\leq \$ 10<\$ 100$ & 1.000 & 0.875 & 0.750 & 0.625 \\
$>\$ 100$ & 2.000 & 1.750 & 1.500 & 1.250 \\
\hline \multicolumn{5}{c}{} \\
\hline For members, principal given up & & & \\
$<\$ 10$ & $\$ 0.280$ & $\$ 0.265$ & $\$ 0.250$ & $\$ 0.250$ \\
$\leq \$ 10<\$ 100$ & 0.425 & 0.400 & 0.375 & 0.375 \\
$>\$ 100$ & 0.850 & 0.800 & 0.750 & 0.750 \\
\hline
\end{tabular}


Table 2: Historical Municipal Sample.

Summary statistics for New York City municipal bonds trading on the NYSE over 292 trading days from July 1, 1926 through March 31, 1930. The Mean Spread is the average bid-ask spread from quotes at 11 a.m. each day. The Mean Price Impact is the average distance between transaction prices and the midpoint of the spread.

\begin{tabular}{lrrrrrr}
\hline Issued & Coupon & $\begin{array}{r}\text { Trade } \\
\text { days } \\
\text { per year }\end{array}$ & $\begin{array}{r}\text { Volume } \\
\text { per year } \\
\mathbf{( 1 9 2 6} \mathbf{\$})\end{array}$ & $\begin{array}{r}\text { Volume } \\
\text { per year } \\
\mathbf{( 2 0 0 3} \mathbf{\$})\end{array}$ & $\begin{array}{r}\text { Mean } \\
\text { Spread }\end{array}$ & $\begin{array}{r}\text { Mean } \\
\text { Price } \\
\text { Impact }\end{array}$ \\
\hline 1904 & 3.50 & 18.00 & 87.00 & 906.06 & $0.73 \%$ & $0.20 \%$ \\
1907 & 4.50 & 42.00 & 147.00 & 1530.93 & $0.64 \%$ & $0.19 \%$ \\
1908 & 4.00 & 14.00 & 66.00 & 687.36 & $0.60 \%$ & $0.38 \%$ \\
1909 & 4.00 & 30.00 & 90.00 & 937.31 & $0.48 \%$ & $0.25 \%$ \\
1911 & 4.25 & 35.00 & 159.00 & 1655.91 & $0.48 \%$ & $0.16 \%$ \\
1914 & 4.25 & 21.00 & 152.00 & 1583.01 & $0.61 \%$ & $0.29 \%$ \\
\hline Mean & 4.08 & 26.67 & 116.83 & 1216.76 & $0.59 \%$ & $0.25 \%$ \\
\hline
\end{tabular}

Table 3: Average Price Impact for Municipal Bonds, 7/26-12/28.

The body of the table contains average percentage price impact, or implicit half-spread, for trades of different par value.

\begin{tabular}{lrr}
\hline par value & nobs. & \% price impact \\
\hline $1 \mathrm{~K}$ & 108 & 0.2691 \\
$2 \mathrm{~K}$ & 53 & 0.2549 \\
$3-4 \mathrm{~K}$ & 42 & 0.3408 \\
$5-9 \mathrm{~K}$ & 49 & 0.3058 \\
$10-14 \mathrm{~K}$ & 20 & 0.2087 \\
$15-29 \mathrm{~K}$ & 10 & 0.325 \\
$>30 \mathrm{~K}$ & 4 & 0.2992 \\
\hline
\end{tabular}


Table 4: Modern Municipal SAmple.

Summary statistics and descriptive information for New York municipal bonds traded through registered broker-dealers from 2000-2005. Mean Markup is the average percentage profit earned by dealers on round-trip transactions initiated by a purchase from a customer. Volume per year is measured in dollars.

\begin{tabular}{|c|c|c|c|c|c|}
\hline Rating & Issued & Maturity & $\begin{array}{r}\text { Trade } \\
\text { days }\end{array}$ & $\begin{array}{l}\text { Annual } \\
\text { volume }\end{array}$ & $\begin{array}{r}\text { Mean } \\
\text { markup }\end{array}$ \\
\hline AAA_S & 1-Jul-84 & 1-Jun-23 & 0.84 & 88.42 & $2.86 \%$ \\
\hline Insured & 15-Jan-87 & 15-Jun-17 & 18.57 & 1224.15 & $2.37 \%$ \\
\hline Insured & 1-Jun-87 & 15-Jun-17 & 3.58 & 105.26 & $2.31 \%$ \\
\hline Insured & 1-Jun-87 & 15-Jun-17 & 1.68 & 48.42 & $2.48 \%$ \\
\hline Insured & 15-Jan-87 & 15-Jun-17 & 51.58 & 7307.37 & $1.81 \%$ \\
\hline AAA_S & -Oct-93 & 01-Jun-23 & 50.95 & 3605.26 & $2.20 \%$ \\
\hline Insured & 5-Nov-93 & 01-Nov-17 & 42.32 & 1613.68 & $2.60 \%$ \\
\hline Insured & -Oct- 89 & $01-$-Oct-16 & 18.11 & 598.95 & $3.72 \%$ \\
\hline Insured & -Jun-90 & $15-\mathrm{Au}$ & 22.74 & 1600.00 & $3.52 \%$ \\
\hline Insured & 5-Oct-89 & $01-\mathrm{Oc}$ & 24.21 & 1503.16 & $2.80 \%$ \\
\hline Insured & 5-Oct-89 & $01-\mathrm{Oc}$ & 27.58 & 1638.95 & $3.44 \%$ \\
\hline & 23-Feb-90 & $01-\mathrm{Au}$ & 11.79 & 1650.53 & $2.18 \%$ \\
\hline & 26-Sep-90 & 15-Mar-18 & 13.26 & 5703.16 & $4.05 \%$ \\
\hline & 1-Jun-90 & $15-\mathrm{Au}$ & 22.32 & 1925.26 & $3.51 \%$ \\
\hline & -Oct-89 & & 24.00 & 1966.32 & $2.89 \%$ \\
\hline & 23-Feb-90 & $01-A_{1}$ & 3.47 & 612.63 & $3.13 \%$ \\
\hline & & $15-\mathrm{Ma}$ & 35.79 & 5560.00 & $2.90 \%$ \\
\hline Insur & 93 & & 4.11 & & $2.04 \%$ \\
\hline & & $15-\mathrm{N}$ & 0.74 & & $1.60 \%$ \\
\hline & & & 6.32 & 532 & $2.12 \%$ \\
\hline & & & 9.40 & 06 & $2.37 \%$ \\
\hline & & & 6.42 & .00 & $2.04 \%$ \\
\hline & & & 2.53 & .32 & $2.07 \%$ \\
\hline & & & 2.00 & .79 & $2.05 \%$ \\
\hline & & & 103.42 & & $.81 \%$ \\
\hline & & & .42 & .00 & $.00 \%$ \\
\hline & & & 5.37 & & $.83 \%$ \\
\hline & & & 3.05 & & $.30 \%$ \\
\hline & & & 8.84 & & $2.29 \%$ \\
\hline & & & 4.74 & 2920.00 & $2.17 \%$ \\
\hline & & & & & $2.17 \%$ \\
\hline & & & & 2711 & $1.96 \%$ \\
\hline & & & & & $2.23 \%$ \\
\hline & & & 49.93 & 1676.18 & $2.37 \%$ \\
\hline & & & 49.45 & & $2.17 \%$ \\
\hline & & & 57.06 & 13456.97 & $2.33 \%$ \\
\hline & & & 50.53 & 6982.11 & $2.78 \%$ \\
\hline & & & 64.42 & 4020.00 & $1.78 \%$ \\
\hline Insured & 19-Sep-90 & 01-Jul-20 & 85.47 & 31765.47 & $4.22 \%$ \\
\hline Average & & & 34.45 & 3693.43 & $2.40 \%$ \\
\hline
\end{tabular}


Table 5: Average vs. Predicted Trade Costs.

Based on the fitted relationship between liquidity measures and trading costs in the modern sample the Fitted Value predicts trading costs for the the historical sample of bonds.

\begin{tabular}{lrrrrrr}
\hline Maturity & $\begin{array}{r}\text { Trade } \\
\text { days }\end{array}$ & $\begin{array}{r}\text { Volume } \\
(2003 \$)\end{array}$ & $\begin{array}{r}\text { Average } \\
\text { spread }(\%)\end{array}$ & $\begin{array}{r}\text { Plus } \\
\text { commission }\end{array}$ & $\begin{array}{r}\text { Fitted } \\
\text { value }\end{array}$ & Difference \\
\hline 1954 & 18.00 & 906.06 & 0.73 & 1.13 & 2.451 & -1.320 \\
1957 & 42.00 & 1530.93 & 0.64 & 1.04 & 2.196 & -1.158 \\
1958 & 14.00 & 687.36 & 0.60 & 1.00 & 2.486 & -1.488 \\
1959 & 30.00 & 937.31 & 0.48 & 0.88 & 2.306 & -1.428 \\
1960 & 35.00 & 1655.91 & 0.48 & 0.88 & 2.289 & -1.406 \\
1964 & 21.00 & 1583.00 & 0.61 & 1.01 & 2.455 & -1.444 \\
\hline Average & & & & 0.990 & 2.364 & -1.374 \\
\hline
\end{tabular}


Table 6: Number of trades And AVERAge trade Size By YeAr IN SIX CORPorAte Bonds.

\begin{tabular}{lrrrrrr}
\hline & 1943 & 1944 & 1945 & 1946 & 1947 & Average \\
& & & & & & \\
\hline Number of trades & & & & & & \\
Baltimore and Ohio & 1151 & 1925 & 1333 & 652 & 766 & 1165 \\
Great Northern & 435 & 298 & 243 & 181 & 173 & 266 \\
Hudson \& Manhattan & 1269 & 1310 & 1379 & 1372 & 1491 & 1364 \\
American Tobacco & 660 & 639 & 492 & 457 & 631 & 576 \\
Firestone & 1224 & 267 & 168 & 172 & 307 & 428 \\
Saguenay Power & 198 & 113 & 108 & 116 & 51 & 117 \\
& & & & & & \\
Average & 823 & 759 & 621 & 492 & 570 & 653 \\
& & & & & & \\
\hline Average trade size & & & & & & \\
Baltimore and Ohio & 6.64 & 6.83 & 6.25 & 4.77 & 4.12 & 5.72 \\
Great Northern & 4.28 & 3.85 & 3.45 & 3.04 & 2.28 & 3.38 \\
Hudson \& Manhattan & 5.17 & 5.29 & 5.41 & 5.55 & 3.94 & 5.07 \\
American Tobacco & 6.00 & 5.08 & 4.56 & 4.37 & 3.73 & 4.75 \\
Firestone & 4.88 & 3.99 & 4.14 & 3.52 & 3.76 & 4.06 \\
Saguenay Power & 4.39 & 2.83 & 4.00 & 5.58 & 5.63 & 4.49 \\
& & & & & & \\
AVERAGE & 5.23 & 4.64 & 4.64 & 4.47 & 3.91 & 4.58 \\
\hline
\end{tabular}


Table 7: Percentage Bid-Ask Spreads and Average Price Impact for Corporate BONDS.

\begin{tabular}{|c|c|c|c|c|c|c|c|c|c|}
\hline & \multirow[t]{2}{*}{ year } & \multirow{2}{*}{$\begin{array}{r}\% \text { bid-ask } \\
\text { spread }\end{array}$} & \multicolumn{5}{|c|}{ ave. $\%$ price impact } & \multirow[b]{2}{*}{$15-29 \mathrm{~K}$} & \multirow[b]{2}{*}{$>30 \mathrm{~K}$} \\
\hline & & & $1 \mathrm{~K}$ & $2 \mathrm{~K}$ & $3-4 \mathrm{~K}$ & $5-9 \mathrm{~K}$ & $10-14 \mathrm{~K}$ & & \\
\hline \multirow[t]{6}{*}{ American Tobacco } & 1943 & 0.229 & 0.111 & 0.133 & 0.115 & 0.100 & 0.100 & 0.103 & 0.116 \\
\hline & 1944 & 0.291 & 0.146 & 0.140 & 0.171 & 0.159 & 0.124 & 0.165 & 0.259 \\
\hline & 1945 & 0.290 & 0.139 & 0.147 & 0.139 & 0.127 & 0.110 & 0.138 & 0.237 \\
\hline & 1946 & 0.428 & 0.199 & 0.208 & 0.187 & 0.189 & 0.265 & 0.189 & 0.120 \\
\hline & 1947 & 0.420 & 0.177 & 0.176 & 0.186 & 0.189 & 0.123 & 0.162 & 0.121 \\
\hline & $\mathrm{n}$ & 1423 & 832 & 520 & 494 & 664 & 221 & 126 & 22 \\
\hline \multirow[t]{6}{*}{ Firestone } & 1943 & 0.198 & 0.152 & 0.180 & 0.146 & 0.142 & 0.112 & 0.292 & \\
\hline & 1944 & 0.148 & 0.189 & 0.169 & 0.149 & 0.171 & 0.131 & 0.120 & \\
\hline & 1945 & 0.211 & 0.199 & 0.199 & 0.169 & 0.139 & 0.298 & & \\
\hline & 1946 & 0.172 & 0.193 & 0.181 & 0.183 & 0.118 & 0.237 & & \\
\hline & 1947 & 0.247 & 0.285 & 0.268 & 0.220 & 0.120 & 0.205 & 0.124 & \\
\hline & $\mathrm{n}$ & 1426 & 398 & 239 & 224 & 284 & 78 & 34 & 7 \\
\hline \multirow[t]{6}{*}{ Saguenay } & 1943 & 0.214 & 0.241 & 0.242 & 0.301 & 0.350 & 0.090 & 0.188 & \\
\hline & 1944 & 0.227 & 0.267 & 0.210 & 0.180 & 0.253 & & & \\
\hline & 1945 & 0.382 & 0.249 & 0.350 & 0.230 & 0.171 & 0.197 & & \\
\hline & 1946 & 0.147 & 0.243 & 0.205 & 0.198 & 0.185 & 0.208 & 0.302 & \\
\hline & 1947 & 0.232 & 0.473 & 0.265 & 0.340 & 0.216 & 0.299 & & \\
\hline & $\mathrm{n}$ & 1290 & 160 & 111 & 110 & 128 & 49 & 16 & 3 \\
\hline \multirow[t]{6}{*}{ BEO Railroad } & 1943 & 0.885 & 0.480 & 0.502 & 0.496 & 0.476 & 0.473 & 0.565 & 0.593 \\
\hline & 1944 & 0.662 & 0.332 & 0.412 & 0.362 & 0.385 & 0.394 & 0.374 & 0.502 \\
\hline & 1945 & 0.431 & 0.188 & 0.192 & 0.193 & 0.177 & 0.190 & 0.173 & 0.195 \\
\hline & 1946 & 0.847 & 0.059 & 0.476 & 0.349 & 0.352 & 0.352 & 0.284 & 0.418 \\
\hline & 1947 & 1.317 & 0.524 & 0.520 & 0.478 & 0.481 & 0.486 & 0.306 & 0.738 \\
\hline & $\mathrm{n}$ & 1386 & 1580 & 925 & 1062 & 1461 & 598 & 420 & 141 \\
\hline \multirow[t]{6}{*}{ Hudson $\&$ Manhattan } & 1943 & 0.984 & 0.658 & 0.685 & 0.787 & 0.695 & 0.701 & 2.482 & 1.198 \\
\hline & 1944 & 0.888 & 0.516 & 0.503 & 0.634 & 0.595 & 0.555 & 0.495 & 0.606 \\
\hline & 1945 & 0.858 & 0.464 & 0.467 & 0.439 & 0.476 & 0.396 & 0.522 & 0.584 \\
\hline & 1946 & 0.956 & 0.541 & 0.553 & 0.536 & 0.528 & 0.690 & 0.642 & 0.609 \\
\hline & 1947 & 1.494 & 0.716 & 0.766 & 1.033 & 0.998 & 1.260 & 1.026 & 0.858 \\
\hline & $\mathrm{n}$ & 1421 & 1802 & 1149 & 1162 & 1685 & 593 & 367 & 57 \\
\hline \multirow[t]{6}{*}{ Great Northern } & 1943 & 0.522 & 0.396 & 0.408 & 0.790 & 0.188 & 0.291 & 0.415 & 0.198 \\
\hline & 1944 & 0.540 & 0.250 & 0.226 & 0.256 & 0.216 & 0.153 & 0.255 & 0.052 \\
\hline & 1945 & 0.881 & 0.402 & 0.530 & 0.229 & 0.391 & 0.195 & 0.348 & \\
\hline & 1946 & 0.961 & 0.426 & 0.360 & 0.411 & 0.398 & 0.378 & 0.282 & \\
\hline & 1947 & 2.171 & 0.936 & 0.768 & 0.684 & 0.920 & 0.439 & 0.325 & \\
\hline & $\mathrm{n}$ & 1338 & 529 & 253 & 220 & 219 & 63 & 39 & 6 \\
\hline
\end{tabular}


Table 8: Transactions costs By Trade size. Columns 3 and 4 report price impact, the absolute distance of the transaction price from the midpoint, as a fraction of the midpoint, in basis points. Columns 5 and 6 add to the price impact the commission, using the schedule in Table 1 to determine one-way tranactions costs, as a fraction of the midpoint in basis points.

\begin{tabular}{lrrrrr}
\hline $\begin{array}{l}\text { trade size } \\
\text { (thousands) }\end{array}$ & $\begin{array}{r}\text { number } \\
\text { trades }\end{array}$ & \multicolumn{2}{c}{ mrice impact } & & \multicolumn{2}{c}{ m-way cost } \\
\hline 1 & 5301 & 40.42 & 23.67 & 81.63 & 66.23 \\
2 & 3197 & 41.93 & 23.75 & 82.99 & 66.47 \\
3 & 1884 & 40.87 & 23.75 & 73.47 & 56.94 \\
4 & 1388 & 50.10 & 23.87 & 74.76 & 48.87 \\
5 & 2236 & 46.38 & 23.68 & 66.91 & 43.98 \\
6 & 766 & 36.09 & 23.65 & 56.33 & 43.79 \\
7 & 562 & 46.65 & 23.42 & 66.77 & 43.11 \\
8 & 486 & 38.17 & 23.88 & 58.23 & 43.82 \\
9 & 388 & 32.98 & 20.22 & 53.33 & 42.07 \\
10 & 810 & 39.74 & 22.35 & 59.96 & 42.46 \\
11 & 276 & 44.05 & 23.71 & 64.17 & 42.72 \\
12 & 207 & 38.46 & 24.33 & 58.25 & 44.39 \\
13 & 166 & 72.85 & 24.36 & 92.36 & 43.83 \\
14 & 144 & 47.05 & 23.84 & 67.19 & 43.87 \\
15 & 250 & 47.65 & 29.13 & 67.16 & 48.72 \\
20 & 104 & 44.31 & 25.32 & 64.99 & 46.98 \\
25 & 69 & 31.14 & 26.25 & 50.83 & 42.19 \\
30 & 11 & 39.80 & 24.10 & 59.17 & 48.19 \\
35 & 15 & 35.34 & 12.06 & 57.28 & 36.19 \\
40 & 9 & 77.42 & 57.80 & 96.92 & 72.25 \\
50 & 15 & 39.23 & 23.98 & 59.92 & 47.27 \\
\hline & & & & &
\end{tabular}

Table 9: REgRESSion of tRADING COST MEASURES ON TRADE SIZE AND TIME. In columns 1 and 2 , the dependent variable is price impact as a fraction of the midpoint price, measured in basis points. In columns 3 and 4 , the dependent variable includes commission. T-statistics are reported in parentheses.

\begin{tabular}{lrrrrr}
\hline & \multicolumn{2}{c}{ \% price impact } & & \multicolumn{2}{c}{ \% 1-way cost } \\
\cline { 2 - 5 } $\begin{array}{l}\text { explanatory } \\
\text { variable }\end{array}$ & $\begin{array}{r}\text { fixed } \\
\text { effects }\end{array}$ & $\begin{array}{r}\text { no fixed } \\
\text { effects }\end{array}$ & $\begin{array}{r}\text { fixed } \\
\text { effects }\end{array}$ & $\begin{array}{r}\text { no fixed } \\
\text { effects }\end{array}$ \\
\hline \multirow{2}{*}{ intercept } & 19.424 & 33.832 & 65.523 & 75.518 \\
& $(3.629)$ & $(16.403)$ & $(12.220)$ & $(36.618)$ \\
days from 1-1-43 & 0.005 & 0.007 & 0.004 & 0.007 \\
& $(2.723)$ & $(4.238)$ & $(2.463)$ & $(4.220)$ \\
trade size (ln) & 2.258 & 2.900 & -6.650 & -6.324 \\
& $(2.392)$ & $(3.059)$ & $(-7.029)$ & $(-6.670)$ \\
\hline
\end{tabular}




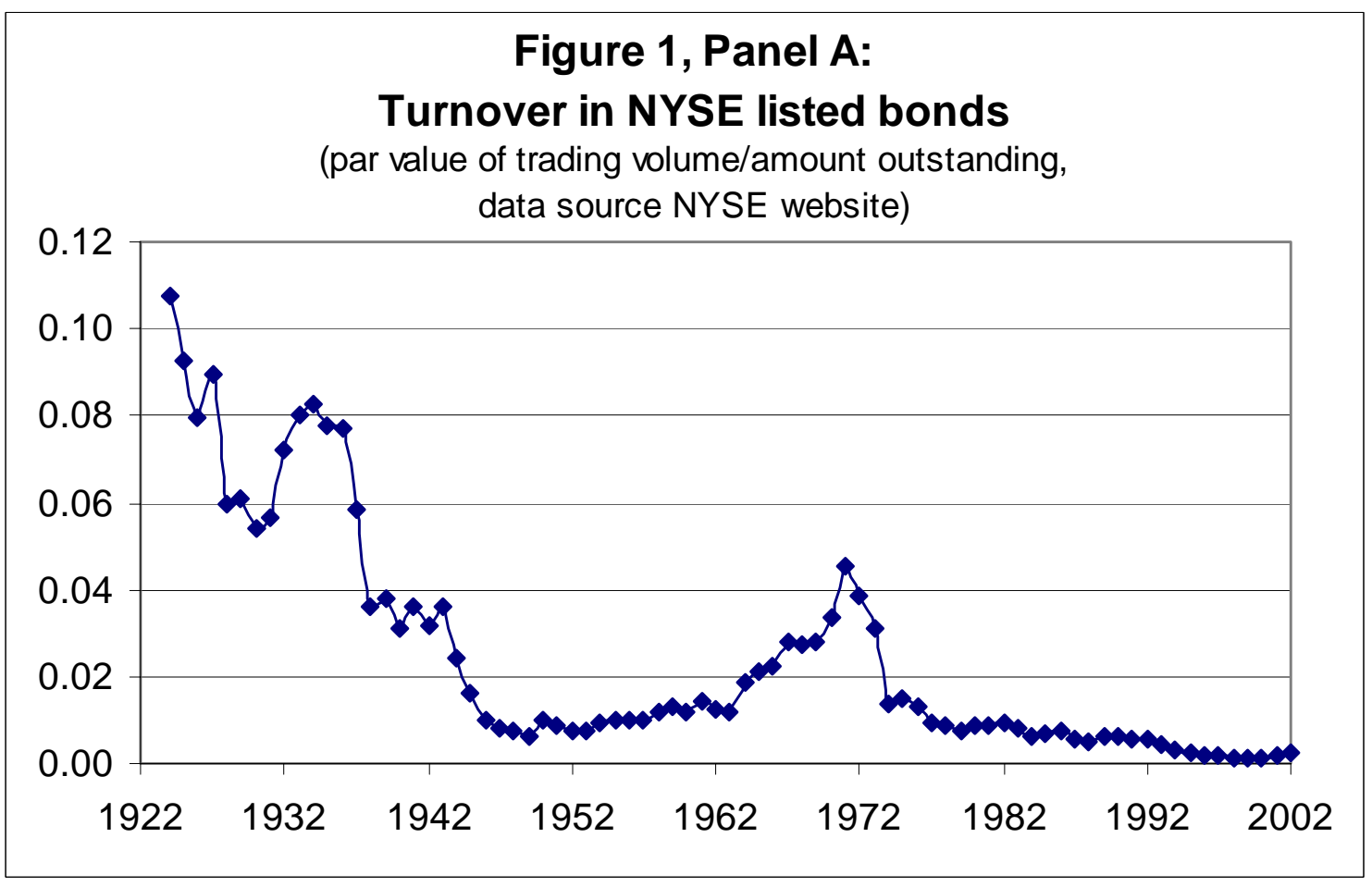

Figure 1, Panel B:

Bond trading on the NYSE as a \% of stock trading

$\$$ value of trading volume. Source: NYSE website

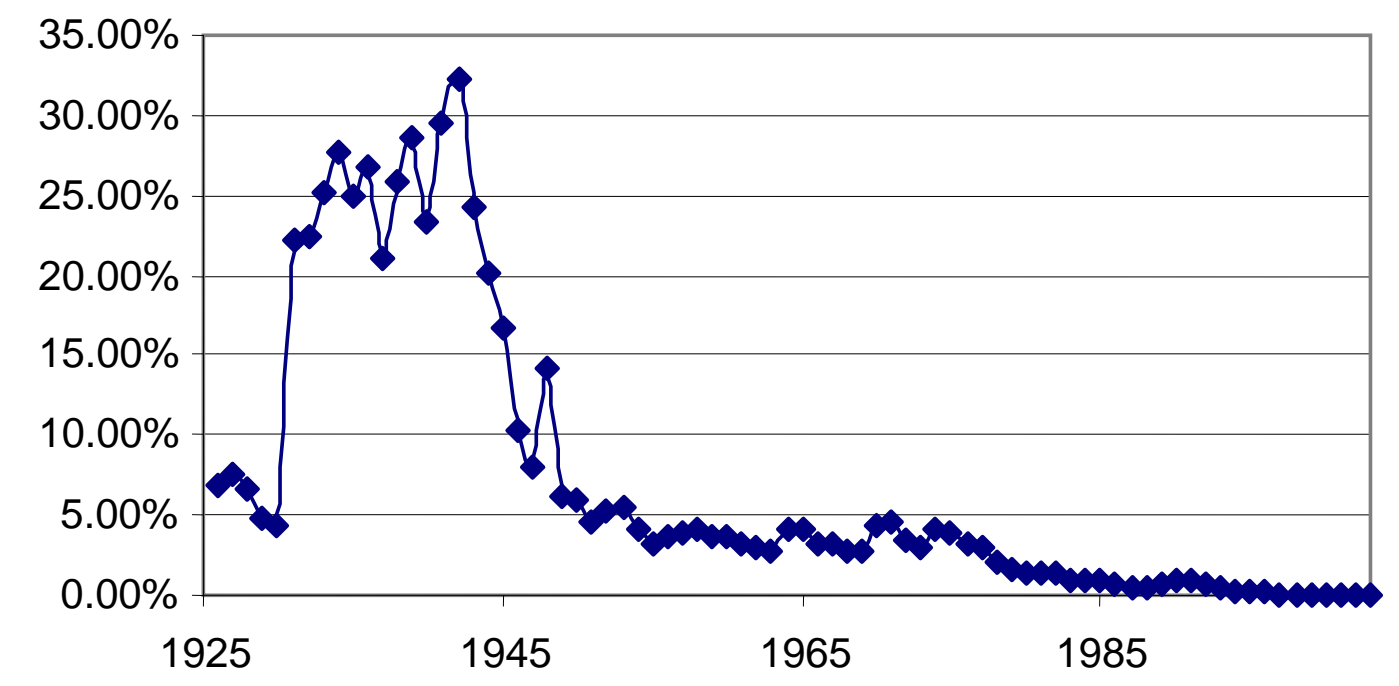




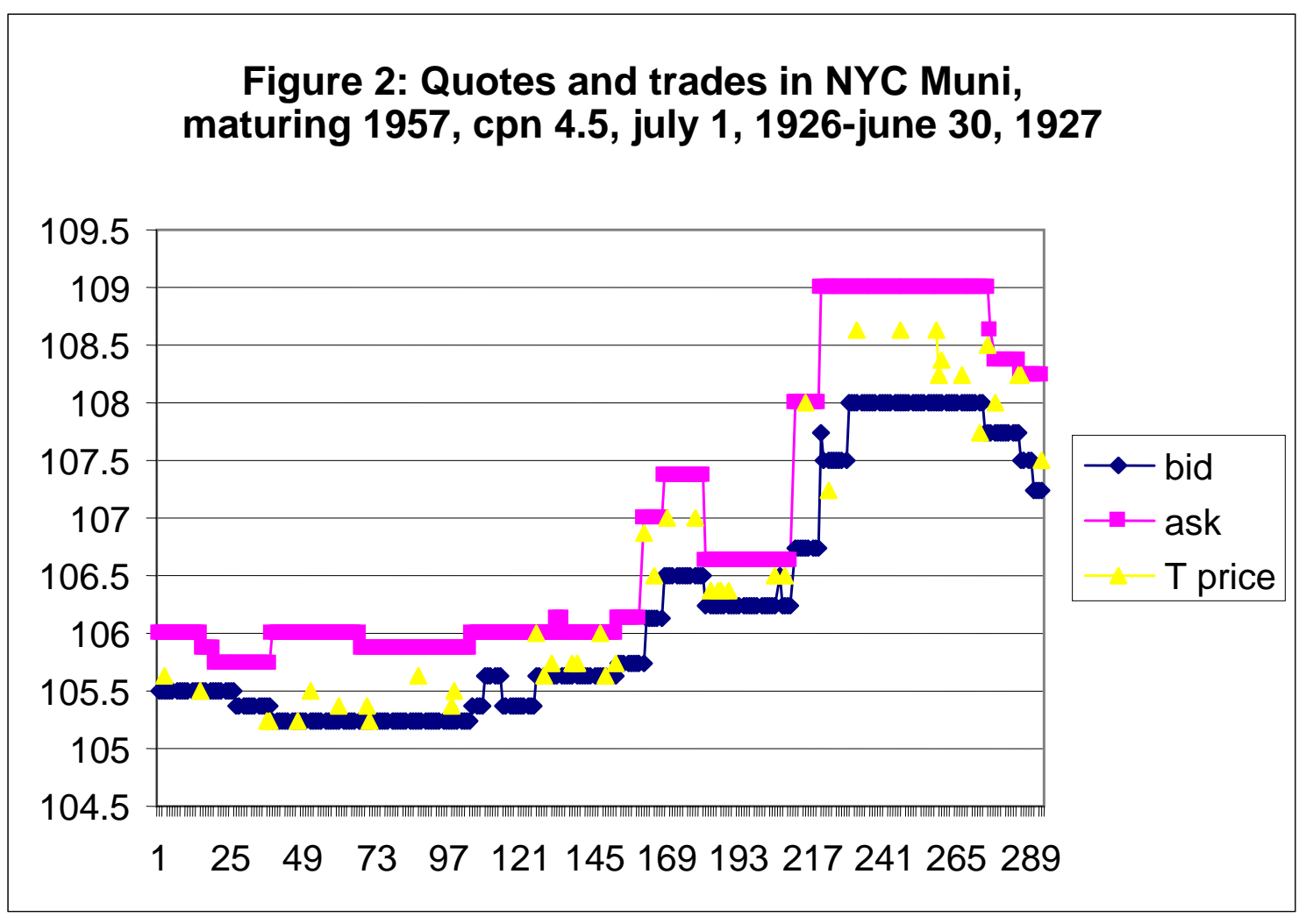




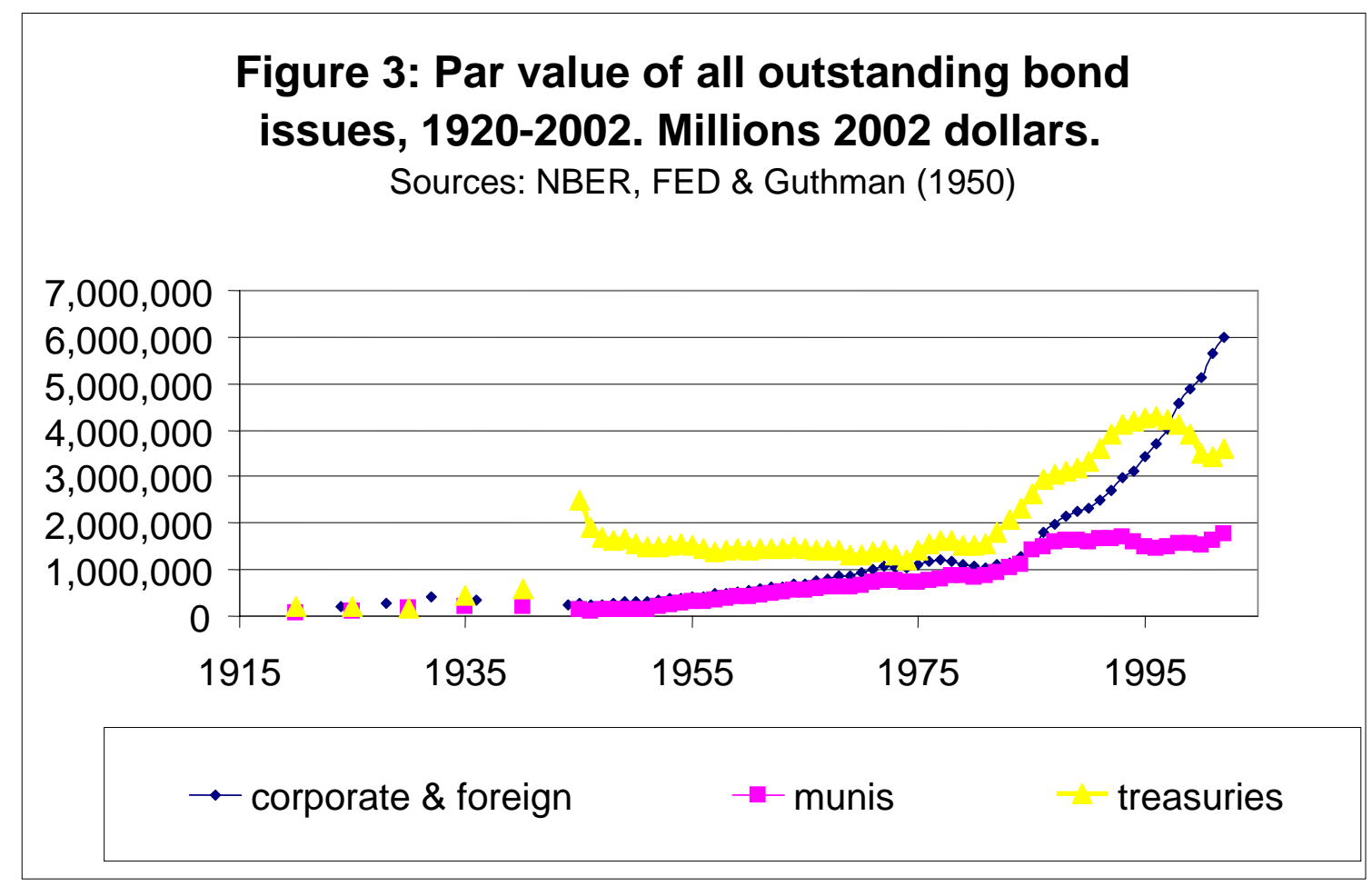




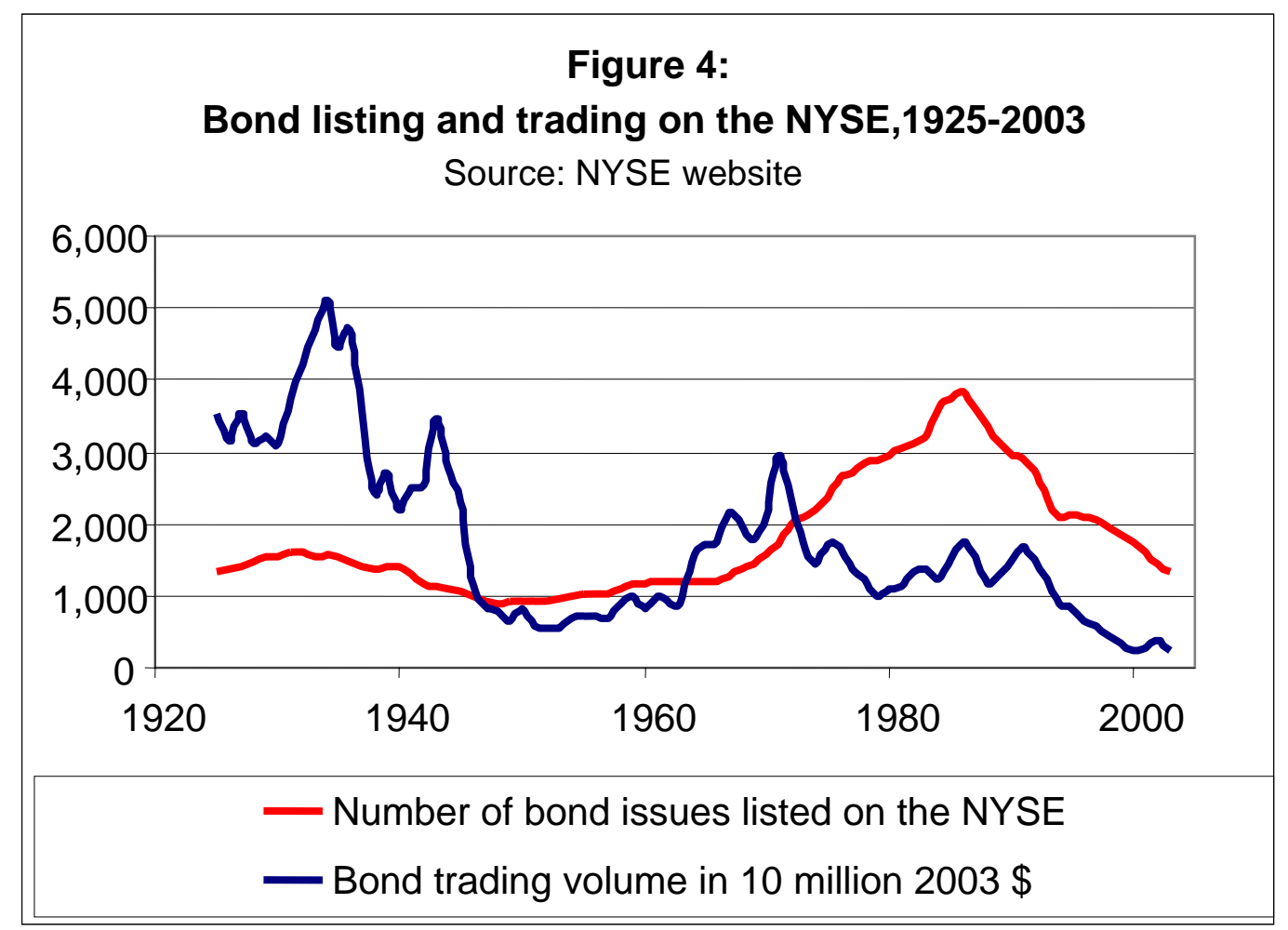




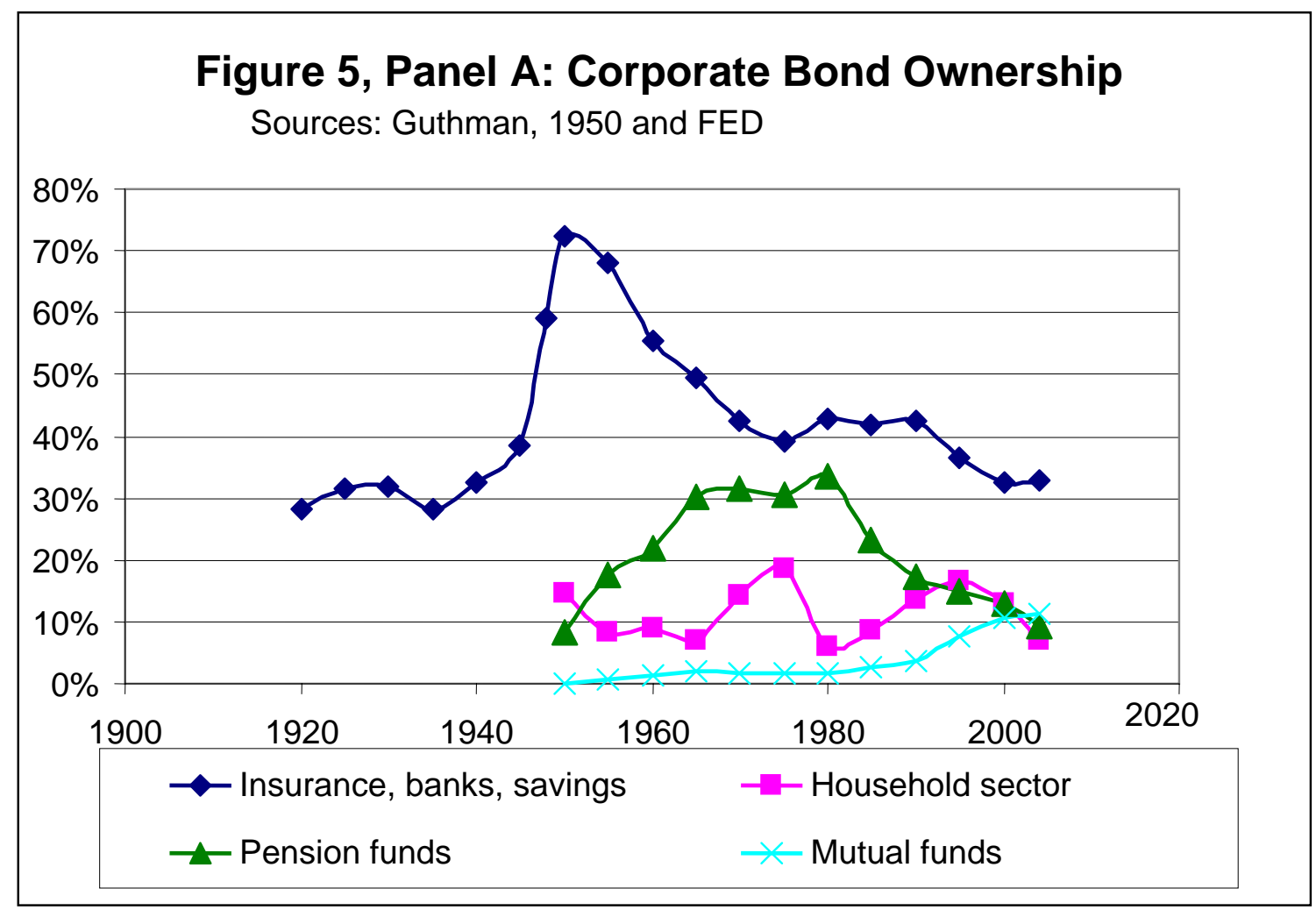

Figure 5, Panel B: Municipal Bond Ownership Sources: Guthman (1950) and FED)

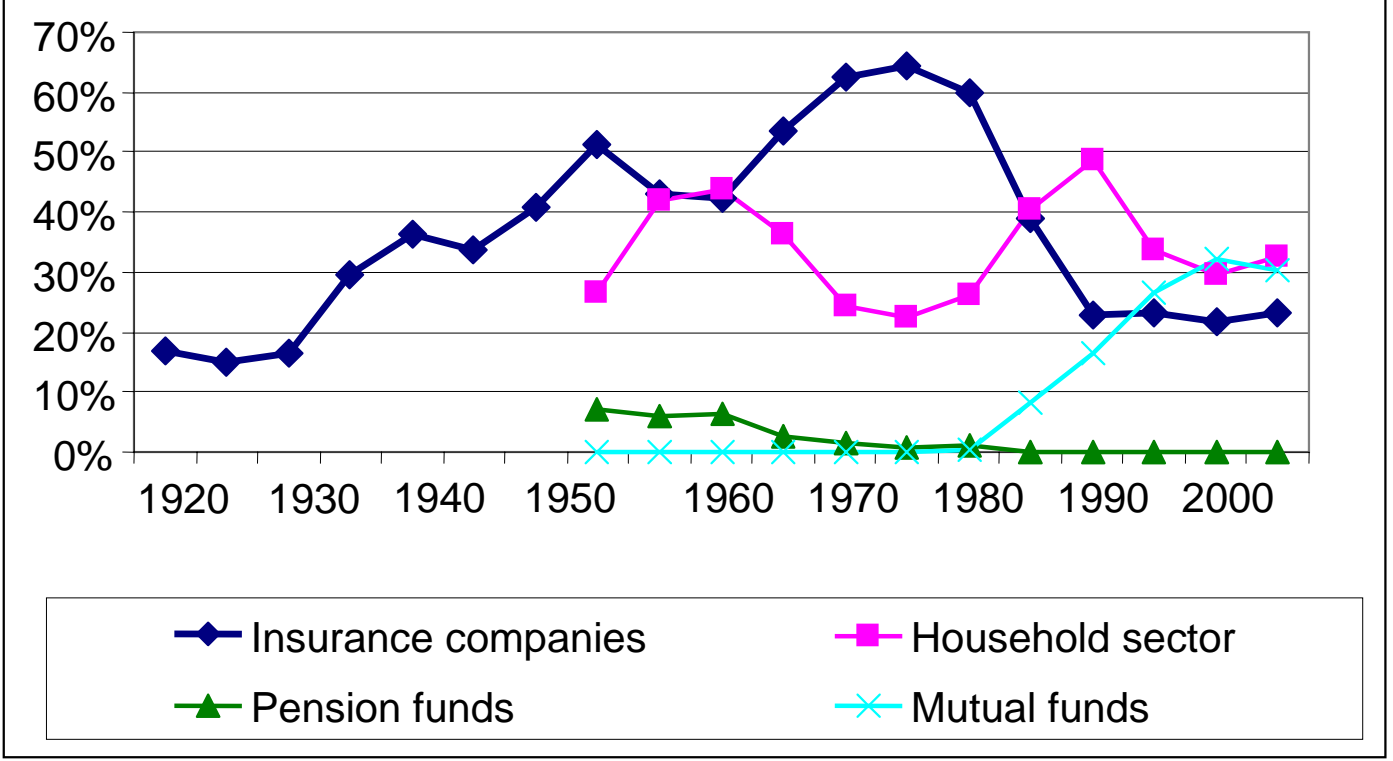




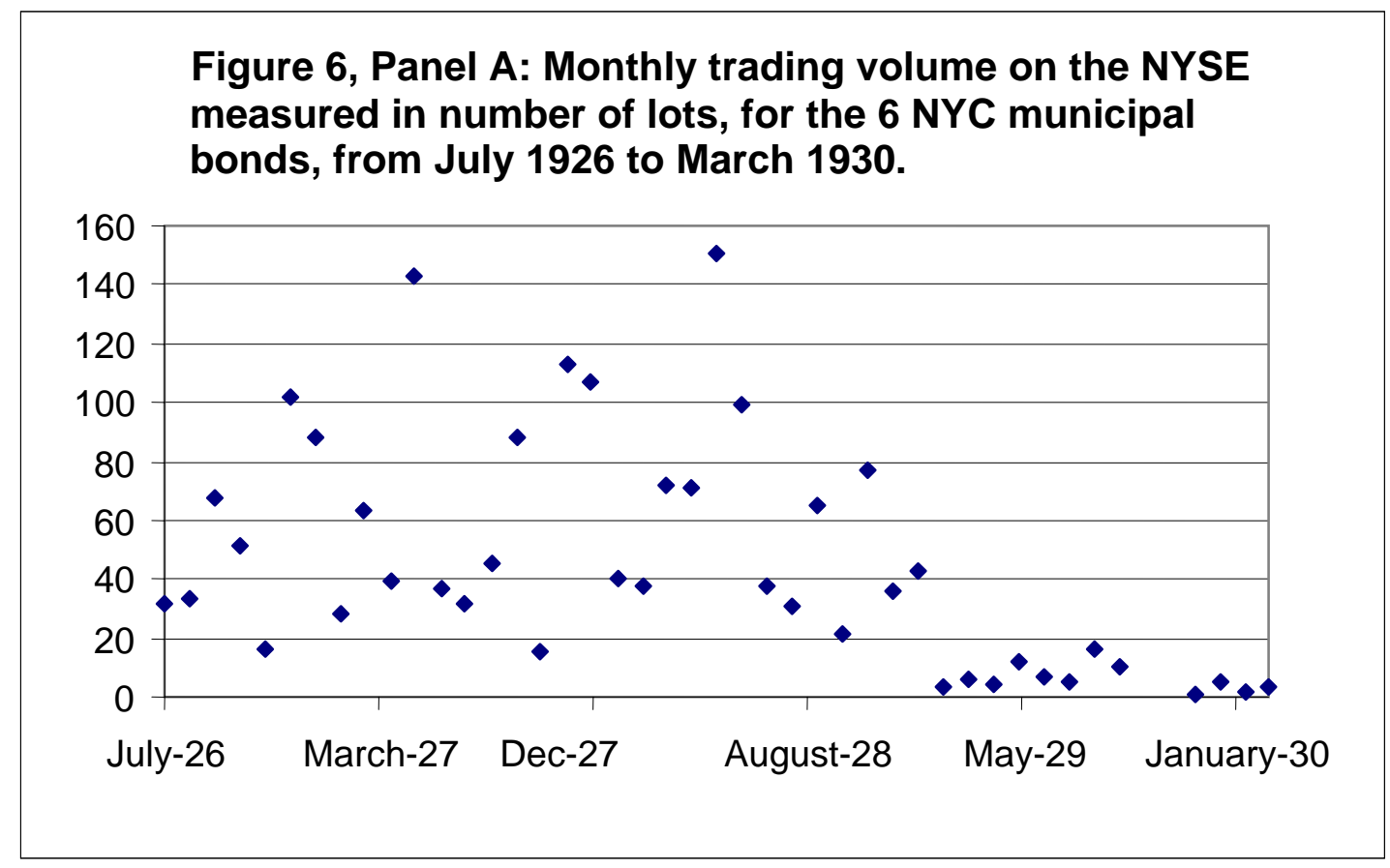

Figure 6, Panel B: Average price impact of trades on the NYSE for the 6 municipal bonds, between July 1926 and March 1930

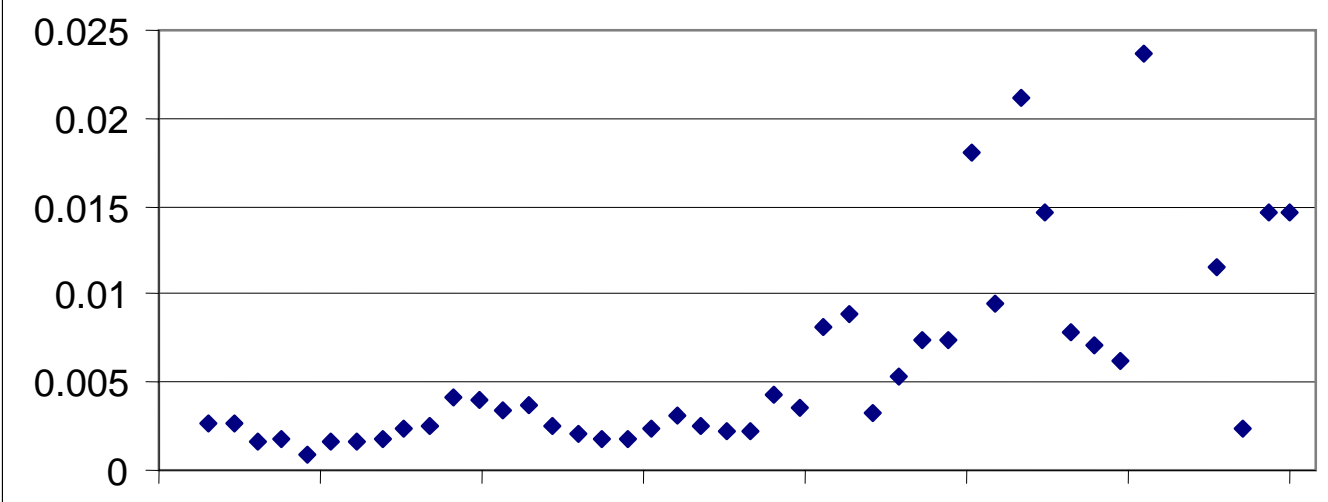

May-26 Nov-27 June-27 Dec-27 July-28 Jan-29 Aug-29 March-30 


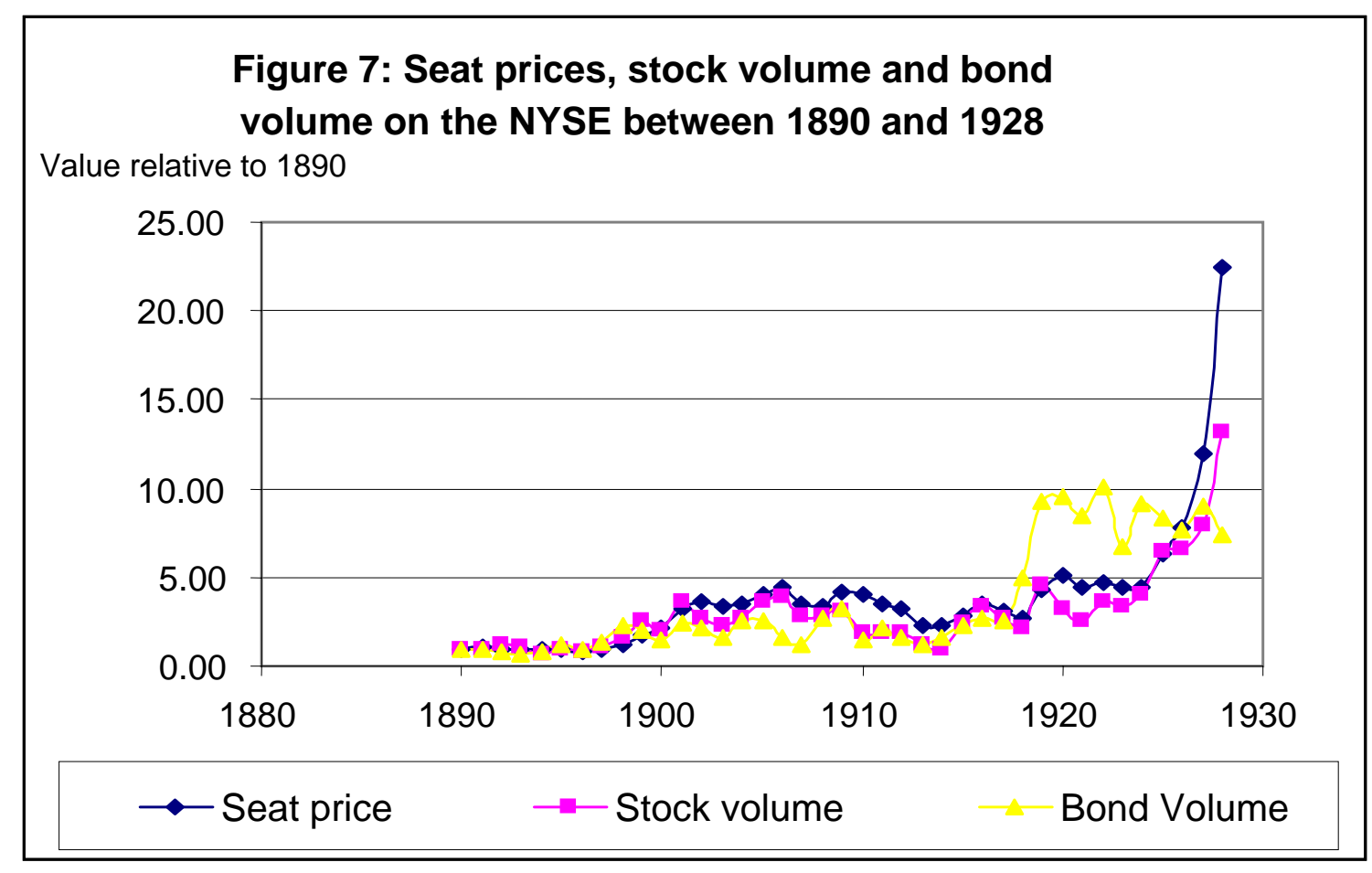

